\title{
Multiple-reaction geobarometry for olivine-bearing igneous rocks
}

\section{Journal Article}

Author(s):

Ziberna, Luca; Green, Eleanor C.R.; Blundy, Jon D.

Publication date:

2017-12

Permanent link:

https://doi.org/10.3929/ethz-b-000224840

Rights / license:

In Copyright - Non-Commercial Use Permitted

Originally published in:

The American Mineralogist 102(12), https://doi.org/10.2138/am-2017-6154 


\title{
Multiple-reaction geobarometry for olivine-bearing igneous rocks
}

\author{
LUCA ZibERNA ${ }^{1, *}$, ELEANOR C.R. GREEN ${ }^{2}$, AND JON D. BLUNDY ${ }^{1}$
}

\author{
${ }^{1}$ School of Earth Science, University of Bristol, BS8 1RJ Bristol, U.K. \\ ${ }^{2}$ Institute of Geochemistry and Petrology, ETH Zurich, 8092 Zurich, Switzerland
}

\begin{abstract}
Efforts to map the vertical distribution of mafic and ultramafic igneous rocks in the Earth's crust and uppermost mantle have long been hampered by the lack of precise geobarometers for the appropriate mineral assemblages. The average $P(\operatorname{av} P)$ method (Powell and Holland 1994) is a multiple-reaction approach that uses a least-squares minimization to average the pressures derived from individual mineral equilibria, taking into account both their uncertainties and correlations. We applied average $P$ to a carefully selected database of published phase-equilibrium experiments in dry to $\mathrm{H}_{2} \mathrm{O}$-saturated, andesitic to basaltic and peridotitic systems at $P=0.6-9.3 \mathrm{kbar}, T=940-1240{ }^{\circ} \mathrm{C}$, with $\log f_{\mathrm{O}_{2}}$ from NNO-2.6 to NNO+3.6 log units (where NNO is nickel-nickel oxide buffer). We made minor modifications to the thermodynamic models of clinopyroxene, spinel, and olivine to improve the accuracy and precision of the results given by the av $P$ method. Tests on the experimental database, using the modified thermodynamic models and spinel + clinopyroxene + olivine + plagioclase equilibria, showed that average $P$ can reproduce the experimental $P$, within the calculated $1 \sigma$ uncertainties $(0.9-2.6 \mathrm{kbar}$; $1.6 \mathrm{kbar}$ on average), for $67 \%$ of the database. No systematic deviations of the calculated pressure $(P)$ with temperature $(T)$ or mineral compositions are observed. Given the large compositional range of the experimental database, these results suggest that the method can be applied to any gabbroic, pyroxenitic, or peridotitic rocks that contain the appropriate phase assemblage clinopyroxene + olivine + plagioclase \pm spinel. For assemblages equilibrated at $P<5 \mathrm{kbar}$, the calculated $P$ shows a slight dependence on $T$, which therefore needs to be well constrained to keep the overall $P$ uncertainties as low as possible. $T$ can be estimated using either available independently calibrated geothermometers or a simple calculation routine suggested in this work. Application of average $P$ to gabbroic xenoliths from Dominica, Lesser Antilles, and to gabbroic and peridotitic xenoliths from Wikieup, Arizona, demonstrates the ability of the method to produce precise $P$ estimates for natural assemblages equilibrated at both mid- and lower crustal conditions, respectively. Depending on the errors on mineral composition, appropriateness of the $T$ estimate, and attainment of equilibrium of the assemblage, $P$ uncertainty for natural rocks is $\leq 1.0 \mathrm{kbar}$. Such a level of precision can help to discriminate between rival petrogenetic processes in subduction zone, intra-plate, and mid-oceanic ridge settings.
\end{abstract}

Keywords: Geobarometry, phase equilibria, mafic crust, gabbros, peridotites; Rates and Depths of Magma Ascent on Earth

\section{INTRODUCTION}

Estimating the pressure $(P)$ and temperature $(T)$ of formation of mafic and ultramafic igneous rocks is a fundamental step in studying the evolution of magmatic systems and the thermal and lithological structure of the crust and crust-mantle transition zone. Developing accurate and precise thermobarometric methods for such rocks is therefore critically important. Conventional methods use phase compositions combined in either empirical or theoretical formulations to derive expressions for $P$ and $T$, with the fundamental assumption that the assemblage of interest attained equilibrium. Commonly used geothermometers and geobarometers for gabbroic and peridotitic rocks are based on single reactions between mineral end-members, often derived by simple regressions of experimental data. Examples include

\footnotetext{
* Present address: Bayerisches Geoinstitut, University of Bayreuth, 95440 Bayreuth, Germany. E-mail: luca.ziberna@uni-bayreuth.de. Special collection papers can be found online at http://www.minsocam.org/MSA/AmMin/special-collections.html.
}

two-pyroxene thermometers (e.g., Wells 1977; Putirka 2008) and barometers (Putirka 2008), olivine-pyroxenes-plagioclase barometers (e.g., Fumagalli et al. 2017), hornblende-plagioclase thermobarometers (e.g., Holland and Blundy 1994; Molina et al. 2015), and magnetite-ilmenite thermometers (e.g., Ghiorso and Evans 2008). Empirical methods based on the composition of a single mineral phase, such as clinopyroxene barometers (e.g., Nimis 1995; Putirka 2008) and amphibole thermobarometers (e.g., Ridolfi and Renzulli 2012), are also available for gabbroic as well as basaltic and andesitic rocks. Mineral-melt thermobarometers potentially produce precise pressure and temperature estimates (Falloon et al. 2007; Putirka 2008, 2016a; Neave and Putirka 2017), but their application to gabbroic or peridotitic rocks is limited to assemblages containing melt in equilibrium with the solid phases (interstitial melt or trapped melt inclusions).

For any given plutonic suite, a barometer or thermometer should meet the following conditions: (1) sufficient precision to discriminate between rival petrogenetic processes; 
(2) applicability over the $P-T$ range of interest; (3) calibration for the compositions of interest; and (4) consistency across the entire suite. Depending on the assemblage, criterion 1 can often be met for temperature, as model errors can be as low as $40{ }^{\circ} \mathrm{C}$ (e.g., Putirka 2008), which is small relative to the range of formation of mafic/ultramafic plutonic rocks $\left(800-1300^{\circ} \mathrm{C}\right)$. However, for existing barometers that are applicable to subsolidus gabbroic assemblages [e.g., two-pyroxene or singleclinopyroxene barometers of Putirka (2008), single-amphibole barometer of Ridolfi and Renzulli (2012)], typical model errors are 3-4 kbar [inferred from experimental data not used in the calibration; see Putirka $(2008,2016 b)$ and Erdmann et al. (2014) for a review]. This is unacceptably high considering the typical pressure range to be investigated (e.g., $<7 \mathrm{kbar}$ for island arcs and intra-oceanic settings). For empirical or semi-empirical single-reaction thermobarometers, condition 2 is usually met, as calibrant phase-equilibrium experiments generally cover a wide range of $P$ and $T$ (e.g., $0-20 \mathrm{kbar}, 800-1400{ }^{\circ} \mathrm{C}$ ). Condition 3 is particularly critical when adopting empirical or semi-empirical thermobarometry, because relationships that are too simplified or that have no thermodynamic basis become unreliable when applied outside the range of the calibration data. For the same reason, some empirical thermobarometers may be sensitive to the buffering effect of phases that are not involved in the reaction, but are present in the assemblage, hampering the application to natural samples with phase assemblages that differ from those in the calibration data set. This issue may be particularly important when single-phase empirical thermobarometers calibrated using suprasolidus (i.e., melt-present) experiments (e.g., Ridolfi and Renzulli 2012) are applied to plutonic rocks equilibrated at subsolidus (i.e., melt-absent) conditions. Finally, condition 4 may be difficult to meet when the rock suite includes samples with different mineral assemblages, requiring the adoption of different, potentially inconsistent, single-reaction thermobarometers calibrated on different experimental data sets.

A potential solution that fulfills all of the above conditions for pressure determination is multiple-reaction barometry, employing an internally consistent data set of thermodynamic data for mineral end-members (e.g., Berman 1988; Holland and Powell $1998,2011)$, along with a set of activity-composition $(a-x)$ relations calibrated for use with the same end-member data set ${ }^{1}$. The multiple-reaction method allows all of the $P$ and $T$ information in a mineral assemblage to be used simultaneously, provided the necessary thermodynamic models exist, via an independent set of reactions among the end-members of the phases (Berman 1991; Gordon 1992; Powell and Holland 1988, 1994, 2008). End-member thermodynamic data and activity-composition $(a-x)$ relations are now available for the majority of rock-forming minerals of the crust and shallow mantle (e.g., Ghiorso and Sack 1995; Holland and Powell 2011; Diener et al. 2007; Green et al. 2007, 2012, 2016; Gualda et al. 2012; White et al. 2014; Jennings and Holland 2015), thus potentially allowing the method to be applied consistently to rock suites across a wide range of mineralogy and composition.

A single reaction among the end-members of phases is sufficient to calculate the value of $P$ at given $T$. However, in a robust application of multiple-reaction barometry, there are several reactions forming an independent set, and the $P$ values are statistically over-determined. Owing to the uncertainties in thermodynamic models and in analyzed mineral compositions, the reactions do not, in general, intersect at the same $P$ - $T$. Therefore, a statistical approach is needed to calculate the optimal $P$. Such an approach must be weighted by the uncertainties affecting each reaction in the independent set, and this weighting must also take into account the correlated influence of these uncertainties on reactions that share end-members (Powell 1985; Powell and Holland 1994). The average $P(\operatorname{av} P)$ method (Powell and Holland 1988, 1994, 2008), is one of the few available algorithms for multiple-reaction thermobarometry that uses a rigorous statistical approach to handle both uncertainties and correlations. The algorithm is accessible via the software THERMOCALC, using the Holland and Powell $(1985,1990,1998,2011)$ internally consistent data set of end-members and, in principle, any suitably encoded $a-x$ relations with the modified regular solution formulations described in Powell and Holland (1993) and Holland and Powell (2003).

The av $P$ algorithm in THERMOCALC has historically been applied to metamorphic rocks, and the development of $a-x$ relations suitable for their use has concentrated on the metamorphic domain. However, following the work of Jennings and Holland (2015) and Green et al. (2016), a set of $a-x$ relations is, for the first time, available for the phases expected in hydrous igneous rocks under crustal and upper mantle conditions. Given the potential of average $P$ to fulfil all the conditions for optimal geobarometry, we evaluated the accuracy of the method and accompanying $a-x$ relations for mafic and ultramafic rocks using a data set of phase-equilibrium experiments in basaltic and peridotitic systems, together with well-equilibrated natural samples, as a test case.

\section{METHODOLOGICAL OVERVIEW AND RATIONALE}

Our aim is to develop a procedure for reliably applying multiple-reaction barometry to crustal-depth mafic and ultramafic igneous rocks. A database of phase-equilibrium experiments (Supplementary ${ }^{2}$ Material 1) was used to evaluate the results obtained with THERMOCALC's av $P$ algorithm (Powell and Holland $1988,1994,2008$ ) and a selection of published thermodynamic models for mineral phases. The thermodynamic models were then refined, where necessary, to minimize systematic discrepancies between the av $P$ calculations and the experimental database. Prior estimates of $T$ and analytical or model uncertainty were explored, both for the experimental database, and for natural samples. Our work focused on rocks containing the assemblage SCOIP (see Table 1 for abbreviations). This assemblage is common in mafic and ultramafic plutonic rocks from various tectonic settings, and appears in a relatively large number of experimental runs. We further tested av $P$ calculations using the sub-assemblage COlP. This yields only three independent reactions, compared with six for SCOIP, and is therefore potentially less robust. However, COlP can be applied to a larger number of experiments and natural samples, including plagioclase peridotites.

Refinement of the thermodynamic models allows the average $P$ approach to satisfy criteria 1 to 3 above. Regarding criterion 4 , the method is devised such that it is possible to apply mutually consistent barometers across a suite of rocks, simply by adding further sets of well-calibrated $a-x$ relations to those for olivine, clinopyroxene, plagioclase, and spinel, using the same internally consistent data set of end-member thermodynamic properties (Holland and Powell 2011).

Supplementary ${ }^{2}$ Material 2 describes how to obtain software and input files for applying the average $P$ approach to SCOIP and COIP assemblages, and provides an example calculation.

\section{EXPERIMENTAL DATABASE}

We assembled a database of published phase-equilibrium experiments in natural andesitic to basaltic and peridotitic systems whose run products contain, at least, olivine, clinopyroxene, 
TABLE 1. Abbreviations used in this work

\begin{tabular}{|c|c|}
\hline$\overline{\text { SCOIP }}$ & 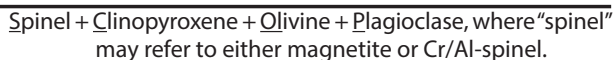 \\
\hline COIP & Clinopyroxene + Olivine $+\underline{\text { Plagioclase }}$ \\
\hline apfu & atoms per formula unit \\
\hline $\mathrm{mg} \#$ & $\mathrm{Mg} /\left(\mathrm{Mg}+\mathrm{Fe}^{2+}\right)$ \\
\hline NNO & nickel-nickel oxide buffer \\
\hline$P_{\text {exp }}, T_{\text {exp }}$ & $\begin{array}{l}\text { measured pressure, temperature of the experiment } \\
\text { initial quesses of pressure and temperature }\end{array}$ \\
\hline$\Delta G_{\mathrm{r}}^{\circ}$ & $\begin{array}{l}\text { Gibbs free energy difference in } \mathrm{kJ} \text { for the reaction } r \text { among } \\
\text { the pure end-members }\end{array}$ \\
\hline$v_{i}$ & reaction coefficient for end-member $i$, at $P, T$ \\
\hline$\mu_{i}$ & total chemical potential for end-member $i$ \\
\hline$\mu_{i}^{\circ}$ & chemical potential of the pure end-member at $P, T$ \\
\hline $\mathrm{R}$ & gas constant $(0.0083144 \mathrm{~kJ} / \mathrm{K} \cdot \mathrm{mol})$ \\
\hline$W_{(m, n)}^{j}$ & $\begin{array}{l}\text { pairwise interaction energy representing non-ideal enthalpy } \\
\text { of mixing between end-members } m \text { and } n \text { in phase } j\end{array}$ \\
\hline$a_{j}$ & activity of end-member $i$ \\
\hline$K_{\mathrm{r}}$ & equilibrium constant for reaction $r$ \\
\hline$\Delta H_{r}$ & enthalpy change for reaction $r$, at $P, T$ \\
\hline$\Delta S_{r}$ & entropy change for reaction $r$, at $P, T$ \\
\hline$\Delta V_{r}$ & volume change for reaction $r$, at $P, T$ \\
\hline$P_{r}$ & pressure at $T_{0}$ for reaction $r$ \\
\hline $\bar{P}$ & average pressure (at $T_{0}$ ) calculated through the av $P$ algorithm \\
\hline$\sigma_{\bar{p}}$ & calculated $1 \sigma$ uncertainty for $\bar{P}$ \\
\hline$\sigma_{\text {fit }}$ & $\begin{array}{c}\text { diagnostic value that measures the appropriateness of the } \\
\text { average, with } \sigma_{\text {fit }}^{2} \text { distributed as } x^{2}\end{array}$ \\
\hline$e_{i}^{*}$ & $\begin{array}{l}\text { uncertainty-normalized residuals in log (activity) for } \\
\text { end-member } i\end{array}$ \\
\hline$H_{i}^{*}$ & $\begin{array}{l}\text { uncertainty-normalized residuals in the enthalpy for } \\
\text { end-member } i\end{array}$ \\
\hline$h_{\mathrm{i}}$ & $\begin{array}{l}\text { hat value, i.e., degree of influence of the end-member } i \text { on } \\
\text { the least-square results }\end{array}$ \\
\hline$T_{\text {ofit }}$ & $\begin{array}{l}T_{0} \text { that produces the av } P \text { result with the minimum } \\
\text { value of } \sigma_{\text {fit }}\end{array}$ \\
\hline SEE & standard error of the estimate \\
\hline
\end{tabular}

and plagioclase. Some experimental data sets were excluded, despite containing the right assemblage, either because: (1) the experiments show clear evidence of disequilibrium (e.g., large compositional inhomogeneity of the run products, significant $\mathrm{Fe}$ loss), or (2) run duration was very short (i.e., $<2 \mathrm{~h}$ ) or (3) mineral compositions were not reported. A reference list of experiments that satisfied these requirements is reported in Supplementary $^{2}$ Material 1 and their $P-T$ conditions are shown in Figure 1. Clinopyroxenes in most of the experiments at $P \geq$ 9 kbar and $T \geq 1150{ }^{\circ} \mathrm{C}$ have low-Ca contents ( $\geq 0.38$ atoms per formula unit, apfu; Bartels et al. 1991; Draper and Johnston 1992; Kinzler and Grove 1992; Fig. 2a). The closure of the solvus separating low- and high-Ca pyroxene compositions is difficult to capture accurately in $a-x$ modeling and, moreover, such low-Ca clinopyroxenes are rare in natural igneous rocks. We therefore excluded the experiments containing these clinopyroxenes from the data set. Additionally, clinopyroxenes from atmospheric pressure experiments $(0.001 \mathrm{kbar})$ show a range of tetrahedral aluminum $\left(\mathrm{Al}^{\mathrm{IV}}=2-\mathrm{Si}[\mathrm{apfu}]\right)$ contents that exceeds that at higher pressures (Fig. 3), suggestive of a complex cation partitioning for 1-atm clinopyroxenes. Existing geobarometers involving Al- and Na-in-clinopyroxene components systematically fail to predict pressure for 1-atm experiments. This has been ascribed to Na-loss during the experiment (Putirka 2008), although, conversely, Mollo et al. (2010) showed that fastgrowing clinopyroxene crystals contain excessive $\mathrm{Na}$ and $\mathrm{Al}$, compensating for depletions in $\mathrm{Si}, \mathrm{Ca}$, and $\mathrm{Mg}$ relative to the equilibrium composition. Considering that some equilibria used in this work involve $\mathrm{Al}$ and $\mathrm{Na}$ partitioning, we therefore removed all 1-atm experiments from the average $P$ data set. Additional

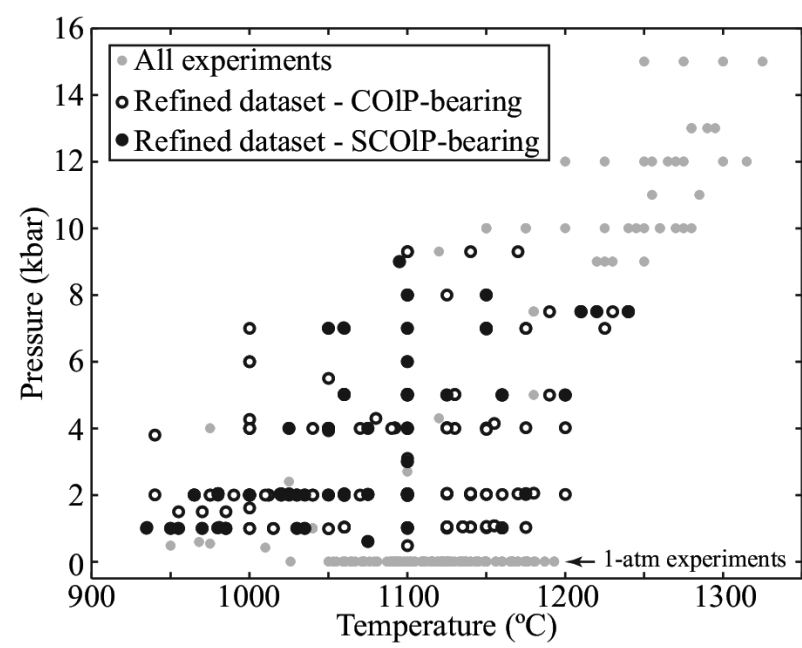

FIGURE 1. $P-T$ conditions of phase-equilibrium experiments in basaltic and peridotitic systems that contain at least olivine, clinopyroxene, and plagioclase in their phase assemblages. Source references for this database are reported in Supplementary ${ }^{2}$ Material 1.

filtering based on the quality of microprobe analyses and possible presence of aberrant data (see Supplementary ${ }^{2}$ Material 1) yielded a final data set of 209 experiments with the COlP assemblage, of which 62 also contain the SCO1P assemblage.

The conditions covered by the refined experimental database are $P=0.5-9.3 \mathrm{kbar}, T=935-1240{ }^{\circ} \mathrm{C}$ (Fig. 1 ), and $\log f_{\mathrm{O}_{2}}$ from $\mathrm{NNO}-2.6$ to $\mathrm{NNO}+3.6 \log$ units. Compositions of olivine, spinel, clinopyroxene, and plagioclase are shown in Figure 2. Olivines are almost pure solid solutions of forsterite and fayalite, with only minor or trace amounts of $\mathrm{Ca}$ and $\mathrm{Mn}$ components $(\mathrm{Ca}$ $<0.025 \mathrm{apfu}$; $\mathrm{Mn}<0.024 \mathrm{apfu})$. Plagioclases are solid solutions of albite and anorthite, with only minor amounts of $\mathrm{K}(<0.12$ apfu) and $\mathrm{Fe}_{\text {tot }}(<0.09$ apfu) components. Spinels show a wide range of composition including magnetites, ulvospinels, and spinels sensu-stricto, with variable amounts of $\mathrm{Cr}$ (Fig. 2c) and $\mathrm{mg \#}$ in the range $0.11-0.89$. Clinopyroxenes are augites with variable $\mathrm{Al}(0.08-0.39 \mathrm{apfu})$ and $\mathrm{Ti}(0.00-0.10 \mathrm{apfu})$ and low $\mathrm{Na}(0.01-0.08 \mathrm{apfu})$. The 62 experiments containing the subset SCOIP cover roughly the same range of $P-T$ conditions and mineral compositions (e.g., Figs. 1, 2a, and 2b), with $\log f_{\mathrm{O}_{2}}$ from NNO-0.1 to $\mathrm{NNO}+3.6$.

\section{AVERAGE-PRESSURE CALCULATIONS: METHODOLOGY \\ Overview of the avP method}

An optimal value of $P, \bar{P}$ may be found by least-squares averaging of multiple independent phase equilibrium constraints, each of which can be formulated as a reaction between endmembers. To find the optimal value is not simply a matter of averaging the values of the $P_{r}$, the pressures obtained from each reaction $r$ in the set, because some end-members appear in more than one reaction. If the pressures of the reactions are adjusted to coincide at $\bar{P}$, the implication is that the calculated chemical potentials of the end-members are being adjusted. Adjustments to chemical potentials must be applied consistently across each of the end-member reactions, meaning that the reactions must be 

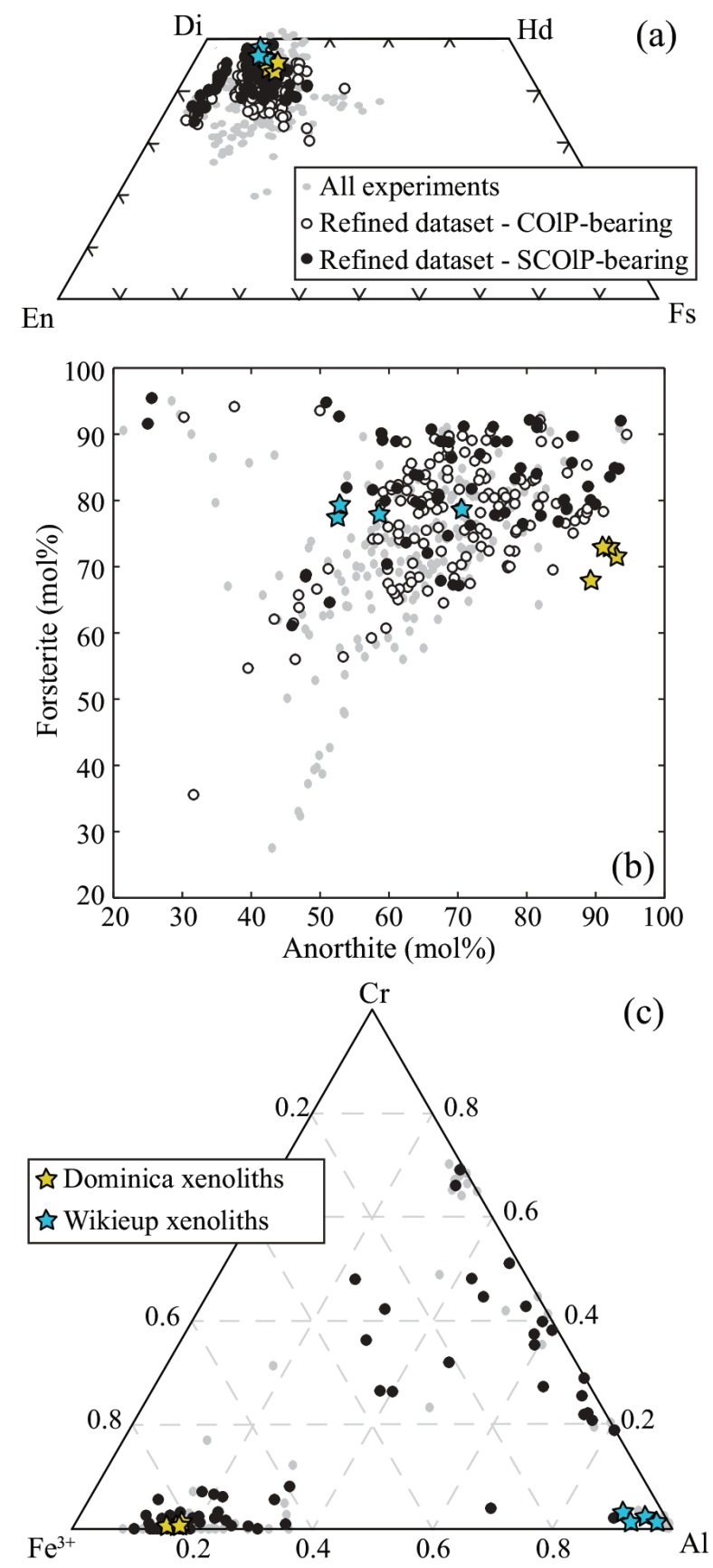

Figure 2. Composition of the mineral phases used for av $P$ calculations on experimental and natural samples. (a) Pyroxene quadrilateral projection (Morimoto et al. 1988). (b) Forsterite content in olivine plotted vs. anorthite content in plagioclase. (c) Trivalent cation plot for spinels $\left[\mathrm{Fe}^{3+}=\mathrm{Fe}^{3+} /\left(\mathrm{Fe}^{3+}+\mathrm{Al}+\mathrm{Cr}\right), \mathrm{Al}=\mathrm{Al} /\left(\mathrm{Fe}^{3+}+\mathrm{Al}+\mathrm{Cr}\right), \mathrm{Cr}=\right.$ $\left.\mathrm{Cr} /\left(\mathrm{Fe}^{3+}+\mathrm{Al}+\mathrm{Cr}\right)\right]$. (Color online.)

moved in a suitably correlated way in $P$ space to coincide at $\bar{P}$. The approach is most powerful if applied via using a set of fully thermodynamic models for the phases, in which the chemical potentials of end-members are constructed from parameters representing other physical properties, such as standard enthalpies,

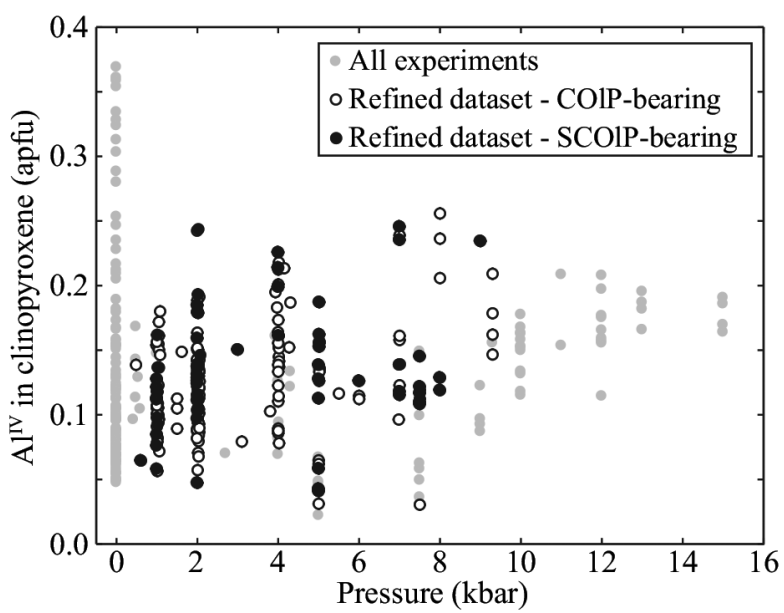

FIGURE 3. Variation of $\mathrm{Al}^{\mathrm{IV}}$ in clinopyroxene with pressure in the experimental database. Note the wide range of $\mathrm{Al}^{\mathrm{IV}}$ for the experiments at $0.001 \mathrm{kbar}$, which is larger than the variations for the entire data set at higher pressures.

within some uncertainty. In this case, the correlated adjustments to the $P_{r}$ required to achieve coincidence at $\bar{P}$, can be made by adjusting the end-member properties, based on a covariance matrix that is known a priori. The method amounts to "least-squares adjustment of indirect observations" (e.g., Mikhail 1976). Such a method, the av $P$ algorithm, is described in detail by Powell and Holland (1988, 1994, 2008), and exploits the Holland and Powell $(1990,1998,2011)$ data set of end-member thermodynamic properties, combined with a set of $a-x$ relations for each solid solution to describe the thermodynamics of mixing (Gordon 1992 discussed a similar procedure). The TWEEQU thermobarometric method of Berman (1991) is of the same type, but does not account for the correlations in the adjustments applied to the $P_{r}$.

A statement of equilibrium for each multiphase reaction, $r$, can be written as

$$
\sum_{i} v_{i} \mu_{i}=\sum v_{i} \mu_{i}^{0}=+\mathrm{R} T \ln K_{r}=\Delta G_{\mathrm{r}}^{\circ}+\mathrm{R} T \ln K_{\mathrm{r}}=0
$$

where, for end-member $i$ in a phase $j$ of specified crystal structure, $v_{i}$ is the reaction coefficient, $\mu_{i}$ is the total chemical potential, and $\mu_{i}^{0}$ is the chemical potential of the pure end-member at $P-T . \Delta G_{\mathrm{r}}^{\circ}$ is the Gibbs free energy difference in kilojoules for the reaction among the pure end-members, $\mathrm{R}$ is the gas constant $(0.0083144$ $\mathrm{kJ} / \mathrm{K} \cdot \mathrm{mol}$ ), and $K_{r}$ is the equilibrium constant, which is given by

$$
K_{r}=\Pi_{\mathrm{i}}\left(a_{i}\right)^{v_{i}}
$$

$a_{i}$ being the activity of end-member $i$.

The av $P$ algorithm, as implemented in THERMOCALC (Powell and Holland 1988), finds the activities of end-members given the observed compositions of the phases, at a likely $P_{0}$ and $T_{0}$ (initial estimates of pressure and temperature), to compute each equilibrium constant $K_{r}$. Taking the corresponding expression for $\Delta G_{\mathrm{r}}^{\circ}$ from the Holland and Powell $(1985,1990,1998,2011)$ data set, it linearizes expression 1 at $T_{0}, P_{0}$, to form the equation from which $P$ is obtained (Fig. 4): 


$$
\mathrm{a}+\mathrm{b} T_{0}+\mathrm{c} P+\mathrm{R} T_{0} \ln K_{\mathrm{r}}=0 .
$$

The $a, b$, and $c$ terms represent the end-member enthalpy, entropy, and volume changes, $\Delta H_{r}, \Delta S_{r}$, and $\Delta V_{r}$, respectively, for the reaction.

Uncertainties in Equation 3 are derived from uncertainties in the properties of individual end-members involved in the reaction. Only the enthalpies and activities of the end-members are considered to be uncertain, since the Holland and Powell data set treats end-member entropies and volumetric properties as exact. The uncertainties in the end-member enthalpies are correlated with each other, and their standard deviations and correlation coefficients are extracted from the Holland and Powell data set. The uncertainties in the activities of end-members are assumed to

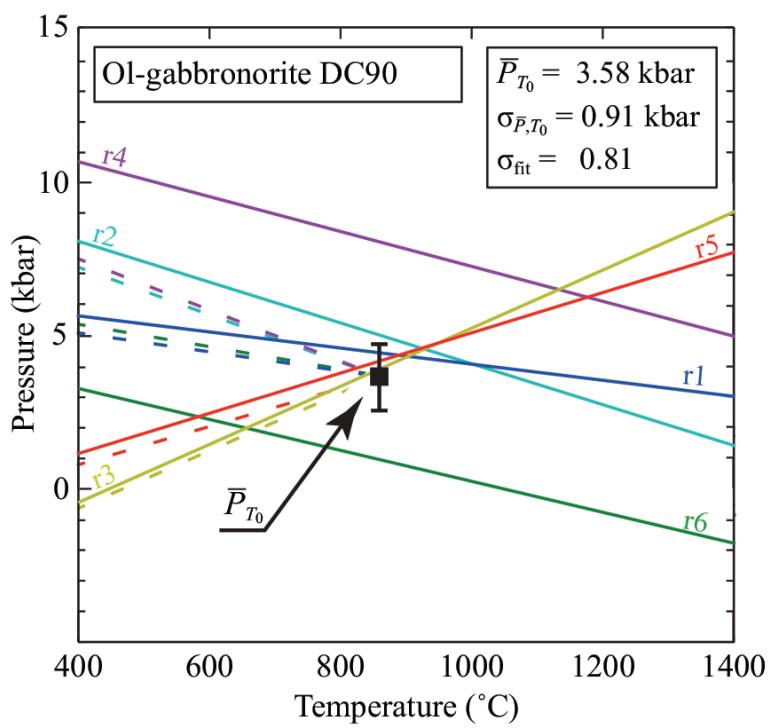

\begin{tabular}{|lr|}
\hline Reactions & $\mathrm{P}_{\mathrm{r}}$ (kbar) \\
r1) fo + an $=$ cenh + cats & $4.3 \pm 1.4$ \\
r2) fa + an $=$ cfs + cats & $4.8 \pm 1.6$ \\
r3) fo + abh = cenh + jd & $4.0 \pm 1.3$ \\
r4) di + an + sp $=$ cenh +2 cats & $8.1 \pm 4.4$ \\
r5) fa + abh $+2 \mathrm{sp}=$ cenh + jd +2 herc & $4.3 \pm 7.2$ \\
r6) $2 \mathrm{fa}+2 \mathrm{abh}+\mathrm{mt}=2 \mathrm{cfs}+2 \mathrm{acm}+$ herc & $0.8 \pm 2.4$ \\
\hline
\end{tabular}

FIGURE 4. Independent set of reactions and av $P$ results at $T_{0}$ $=870{ }^{\circ} \mathrm{C}$ for the spinel + clinopyroxene + olivine + plagioclase (SCO1P) assemblage in olivine-gabbronorite DC90 (Dominica, Lesser Antilles). The reactions are linearized at $T_{0}=870{ }^{\circ} \mathrm{C}$ and $P_{0}=4 \mathrm{kbar}$. In the minimization procedure, av $P$ makes minimal adjustments to the enthalpies and activities of end-members, given their covariance matrices, in order for the reactions to coincide at $\bar{P}$. Reactions derived from the initial input data, i.e., the data set enthalpies and the activities at the measured compositions, are shown as solid curves. Reactions after minimization are shown as dashed curves. The box at the bottom shows the pressures initially obtained from each individual reaction with their associated uncertainties, at $T_{0}=870{ }^{\circ} \mathrm{C}$. For end-member abbreviations see Table 2. A detailed step-by-step demonstration of the same calculation is reported in the Supplementary ${ }^{2}$ Material 2. (Color online.) be independent of each other, and are propagated through from: (1) the analytical uncertainties in the compositional variables, and (2) the uncertainties in the $a-x$ relations, treated simply as uncertainties in the values of $W_{(m, n)}$.

As described in Powell and Holland (1988), the uncertainties in the enthalpies and activities of end-members can be converted into uncertainties on the $a$ and $\ln K_{r}$ terms of Equation 3, taking into account the reaction coefficient of each end-member. A full covariance matrix can ultimately be derived, describing the uncertainties and correlations among the estimates of $P$ from each of the independent reactions $\left(P_{r}\right)$.

Using the reactions and the corresponding covariance matrix, the av $P$ algorithm finds an optimal least-squares average of the $P_{r}$ values, $\bar{P}$, with a well-defined uncertainty $\sigma_{\bar{P}}\left(T_{0}\right)$. Figure $\mathrm{C} 2$ from Powell and Holland (1988) illustrates graphically how two correlated pressures $\left(P_{r}\right)$ are combined to give $\bar{P}$.

Several diagnostic values are displayed following the av $P$ procedure (see Supplementary ${ }^{2}$ Material 2 and Powell and Holland 1994), to assist meaningful application of the method. The diagnostic value $\sigma_{\text {fit }}$ is particularly helpful, providing a measure of how appropriately the pressure information in the independent set of reactions can be combined. If $\sigma_{\text {fit }}$ lies within the cut-off value provided by the $\chi^{2}$ test, representing $95 \%$ confidence, then it is reasonable to assume that the selected phases are indeed in thermodynamic equilibrium, given realistic uncertainties in the mineral analyses and thermodynamic models.

\section{Independent reactions used in this work}

For each of the two assemblages (SCOIP and COIP) considered, we specified the independent set of reactions to be used by the av $P$ algorithm. These were chosen to have generally low uncertainties in their individual pressure estimations, $P_{r}$, implying that they are sensitive to pressure, and also to lie reliably within $20 \mathrm{kbar}$ of the experimental pressures during model refinement. The choice of independent reactions affects the calculated $\bar{P}$, but the variation in $\bar{P}$ is of the order of $\sigma_{\bar{P}}$. For the assemblage SCOIP, the selected reactions are (see example in Supplementary ${ }^{2}$ Material 2 for $\Delta H_{r}, \Delta S_{r}$, and $\Delta V_{r}$ for each reaction):

$$
\begin{aligned}
& \text { cenh }+ \text { cats }=\text { fo }+ \text { an } \\
& \mathrm{Mg}_{2} \mathrm{Si}_{2} \mathrm{O}_{6}+\mathrm{CaAl}_{2} \mathrm{SiO}_{6}=\mathrm{Mg}_{2} \mathrm{SiO}_{4}+\mathrm{CaAl}_{2} \mathrm{Si}_{2} \mathrm{O}_{8} \\
& \mathrm{cfs}+\mathrm{cats}=\mathrm{fa}+\mathrm{an} \\
& \mathrm{Fe}_{2} \mathrm{Si}_{2} \mathrm{O}_{6}+\mathrm{CaAl}_{2} \mathrm{SiO}_{6}=\mathrm{Fe}_{2} \mathrm{SiO}_{4}+\mathrm{CaAl}_{2} \mathrm{Si}_{2} \mathrm{O}_{8} \\
& \text { cenh }+\mathrm{jd}=\text { fo }+\mathrm{abh} \\
& \mathrm{Mg}_{2} \mathrm{Si}_{2} \mathrm{O}_{6}+\mathrm{NaAlSi}_{2} \mathrm{O}_{6}=\mathrm{Mg}_{2} \mathrm{SiO}_{4}+\mathrm{NaAlSi}_{3} \mathrm{O}_{8} \\
& \text { cenh }+2 \text { cats }=\mathrm{di}+\text { an }+\mathrm{sp} \\
& \text { cenh }+\mathrm{jd}+2 \text { herc }=\mathrm{fa}+\mathrm{abh}+2 \mathrm{sp} \\
& \mathrm{Mg}_{2} \mathrm{Si}_{2} \mathrm{O}_{6}+\mathrm{NaAlSi}_{2} \mathrm{O}_{6}+2 \mathrm{FeAl}_{2} \mathrm{O}_{4}= \\
& \mathrm{Fe}_{2} \mathrm{SiO}_{4}+\mathrm{NaAlSi}_{3} \mathrm{O}_{8}+2 \mathrm{MgAl}_{2} \mathrm{O}_{4} \\
& 2 \mathrm{cfs}+2 \mathrm{acm}+\text { herc }=2 \mathrm{fa}+2 \mathrm{abh}+\mathrm{mt} \\
& 2 \mathrm{Fe}_{2} \mathrm{Si}_{2} \mathrm{O}_{6}+2 \mathrm{NaFeSi}_{2} \mathrm{O}_{6}+\mathrm{FeAl}_{2} \mathrm{O}_{4}= \\
& 2 \mathrm{Fe}_{2} \mathrm{SiO}_{4}+2 \mathrm{NaAlSi}_{3} \mathrm{O}_{8}+\mathrm{Fe}_{3} \mathrm{O}_{4}
\end{aligned}
$$$$
\mathrm{Mg}_{2} \mathrm{Si}_{2} \mathrm{O}_{6}+2 \mathrm{CaAl}_{2} \mathrm{SiO}_{6}=\mathrm{CaMgSi}_{2} \mathrm{O}_{6}+\mathrm{CaAl}_{2} \mathrm{Si}_{2} \mathrm{O}_{8}+\mathrm{MgAl}_{2} \mathrm{O}_{4}
$$ 
where the number of independent reactions is equal to $s-c$, with $s$ being the number of end-members and $c$ the number of components involved in mixing (see Table 2).

For COIP, an independent set contains three reactions. The natural choice is simply those of the set of reactions $1-6$ that do not involve end-members of spinel solid solution, i.e., reactions 1,2 , and 3 .

\section{Thermodynamic models}

We employed the internally consistent thermodynamic data set of Holland and Powell (2011) and an initial selection of published $a-x$ relations that are appropriate for use with this data set: the models for plagioclase, clinopyroxene, olivine, and spinel were taken, respectively from Holland and Powell (2003), Green et al. (2016), Hackler and Wood (1989), and Bryndzia and Wood (1990). Specifically, these $a-x$ relations are regular solution models (one-parameter Margules solutions), with mixing on sites, allowing for asymmetry introduced via a van Laar parameter applied to each end-member.

During our development of a procedure for application of average $P$ to igneous rocks, a major requirement was to make modifications to the thermodynamic models (end-member properties and/or $a-x$ relations) to achieve accurate estimation of $\bar{P}$ values for our experimental database. Many of these modifications involved the adjustment of end-member Gibbs energy functions from the data set, $G^{\mathrm{ds}}(P, T)$, by functions $\Delta G^{\mathrm{mod}}(P, T)$, such that for end-member $i, G_{i}(P, T)=G_{i}^{\mathrm{ds}}(P, T)+\Delta G_{i}^{\bmod }(P, T)=G_{i}^{\mathrm{ds}}(P, T)$ $+\mathrm{a}+\mathrm{b} T+\mathrm{c} P$ (the constants $\mathrm{a}, \mathrm{b}$, and $\mathrm{c}$ may be considered to represent enthalpy, entropy, and volume terms, respectively). Additionally we made minor structural changes to the $a-x$ relations and adjusted some of the interaction energies, $W(m, n)$.

By repeatedly assessing the results of average $P$ run on the experimental database as described below, we adopted the following thermodynamic models for clinopyroxene, olivine, and spinel. We did not modify the Holland and Powell (2003) models for plagioclase, an asymmetric solution between high-albite, anorthite, and sanidine. Model end-members are listed in Table 2,

TABLE 2. Solid solutions and compositional end-members used in this work

\begin{tabular}{|c|c|c|c|c|c|}
\hline Solid solution & End-member & Abbreviation & Formula & SCOIP & COIP \\
\hline \multirow[t]{2}{*}{ Olivine } & Forsterite & fo & $\mathrm{Mg}_{2} \mathrm{SiO}_{4}$ & $x$ & $\mathrm{x}$ \\
\hline & Fayalite & $\mathrm{fa}$ & $\mathrm{Fe}_{2} \mathrm{SiO}_{4}$ & $x$ & $\mathrm{x}$ \\
\hline \multirow[t]{5}{*}{ Spinel } & Spinel & $\mathrm{sp}$ & $\mathrm{MgAl}_{2} \mathrm{O}_{4}$ & $x$ & \\
\hline & Hercynite & herc & $\mathrm{FeAl}_{2} \mathrm{O}_{4}$ & $x$ & \\
\hline & Magnetite & $\mathrm{mt}$ & $\mathrm{Fe}_{3} \mathrm{O}_{4}$ & $\mathrm{x}$ & \\
\hline & Picrochromite $^{a}$ & picr & $\mathrm{MgCr}_{2} \mathrm{O}_{4}$ & & \\
\hline & Ulvöspinel $^{a}$ & usp & $\mathrm{Fe}_{2} \mathrm{TiO}_{4}$ & & \\
\hline \multirow[t]{6}{*}{ Clinopyroxene } & Diopside & di & $\mathrm{CaMgSi}_{2} \mathrm{O}_{6}$ & $x$ & \\
\hline & Clinoenstatite & cenh & $\mathrm{Mg}_{2} \mathrm{Si}_{2} \mathrm{O}_{6}$ & $x$ & $\mathrm{x}$ \\
\hline & Clinoferrosilite & $\mathrm{cfs}$ & $\mathrm{Fe}_{2} \mathrm{Si}_{2} \mathrm{O}_{6}$ & $x$ & $\mathrm{x}$ \\
\hline & Jadeite & jd & $\mathrm{NaAlSi}{ }_{2} \mathrm{O}_{6}$ & $x$ & $\mathrm{x}$ \\
\hline & Acmite & $\mathrm{acm}$ & $\mathrm{NaFeSi}_{2} \mathrm{O}_{6}$ & $x$ & \\
\hline & Ca-tschermak & cats & $\mathrm{CaAl}_{2} \mathrm{SiO}_{6}$ & $x$ & $\mathrm{x}$ \\
\hline \multirow[t]{3}{*}{ Plagioclase } & High-albite & abh & $\mathrm{NaAISi}{ }_{3} \mathrm{O}_{8}$ & $x$ & $\mathrm{x}$ \\
\hline & Anorthite & an & $\mathrm{CaAl}_{2} \mathrm{Si}_{2} \mathrm{O}_{8}$ & $x$ & $\mathrm{x}$ \\
\hline & Sanidine $^{a}$ & san & $\mathrm{KAISi}_{3} \mathrm{O}_{8}$ & & \\
\hline
\end{tabular}

Notes: Columns SCOIP and COIP show which end-members are included in the avP calculations using the SCOIP and COIP equilibria, respectively. End-members are described in the Holland and Powell (2011) data set, using the abbreviations shown, with the exception of cenh and cfs.

${ }^{a}$ End-members for which balanced reactions cannot be written. Note that these end-members are still considered in the calculations of the activities of the endmembers involved in the reactions. and a full description of the $a-x$ relations and end-member thermodynamic data can be found in the Supplementary ${ }^{2}$ Material 3.

Clinopyroxene. The starting point for the clinopyroxene $a-x$ relations was the "augite model" of Green et al. (2016) that entails mixing of $\left[\mathrm{Mg}, \mathrm{Fe}^{2+}, \mathrm{Al}, \mathrm{Fe}^{3+}\right]$ on the $\mathrm{M} 1,\left[\mathrm{Na}, \mathrm{Ca}, \mathrm{Mg}, \mathrm{Fe}^{2+}\right]$ on the $\mathrm{M} 2$, and $[\mathrm{Si}, \mathrm{Al}]$ on the tetrahedral sites. The end-members high-temperature clinoenstatite (cenh) and clinoferrosilite (cfs) do not appear in the Holland and Powell (2011) data set, but are constructed by adding $\Delta G_{i}^{\text {trans }}(P, T)$ terms to the Gibbs energy functions for ortho-enstatite (en) and ortho-ferrosilite (fs), respectively (Green et al. 2016), where $\Delta G_{i}^{\mathrm{trans}}(P, T)$ represents the Gibbs energy change of the $\mathrm{Pbca}-\mathrm{C} 2 / \mathrm{c}$ transition. The model incorporates order-disorder of $\mathrm{Fe}^{2+}-\mathrm{Mg}$ across $\mathrm{M} 1$ and $\mathrm{M} 2$, expressed via the proportions of an end-member fmc, $\mathrm{Fe}^{\mathrm{M} 2} \mathrm{Mg}^{\mathrm{M} 1} \mathrm{Si}_{2} \mathrm{O}_{6}$. Like the cenh and cfs end-members, the fmc end-member does not appear in the data set, but has a Gibbs energy function that can be expressed as $1 / 2\left[G_{\text {cenh }}(P, T)+G_{\text {cfs }}(P, T)\right]+\Delta G_{\text {fims }}^{\text {od }}=1 / 2\left[G_{\text {en }}^{\text {ds }}(P, T)+\right.$ $\left.G_{\mathrm{fs}}^{\mathrm{ds}}(P, T)+\Delta G_{\mathrm{en}}^{\mathrm{trans}}(P, T)+\Delta G_{\mathrm{fs}}^{\mathrm{trans}}(P, T)\right]+\Delta G_{\mathrm{fms}}^{\mathrm{od}}$, where $\Delta G_{\mathrm{fms}}^{\mathrm{od}}$ is the Gibbs energy change of ordering to form fmc from a disordered 1:1 mixture of cenh and cfs. The model also includes Si-Al orderdisorder on the tetrahedral site, but whereas in Green et al. (2016) this order-disorder was expressed explicitly, by including both an ordered and a disordered $\mathrm{Ca}$-Tschermaks end-member in the solid solution, we here made a minor simplification by replacing the ordered and disordered Ca-Tschermaks end-members with a single end-member, cats, from the Holland and Powell (2011) data set, for which the thermodynamic properties reflect disordering with temperature. This makes negligible difference to the calculations.

Three problems that emerged during testing of the av $P$ procedure were linked to the clinopyroxene model:

(1) Calculations on the COIP assemblage tended to produce $\bar{P}$ estimates that exceeded experimental pressures by $\sim 5 \mathrm{kbar}$.

(2) The av $P$ diagnostics (see Supplementary ${ }^{2}$ Material 2) for the calculations on the SCOIP assemblage suggested that the clinopyroxene end-members Ca-Tschermaks and jadeite were particularly likely to exhibit large, uncertainty-normalized residuals in activity, $e^{*}$, and that cenh strongly influenced $\bar{P}$.

(3) When $\bar{P}$ was calculated over a range of $T_{0}$, values of $\sigma_{\text {fit }}$ and $\sigma_{\bar{P}}$ were typically smaller for small values of temperature, with minima occurring at temperatures $<T_{\text {exp }}$. This showed that the models' temperature-dependences were poorly calibrated. This is a significant observation since the method of calculating $\bar{P}$ at multiple $T_{0}$ may be used to estimate the equilibration temperature of a sample, as discussed below.

In response to problem 3 , we investigated the model reaction $\mathrm{Mg}_{2} \mathrm{SiO}_{4}$ (fo) $+\mathrm{Fe}_{2} \mathrm{Si}_{2} \mathrm{O}_{6}$ (cfs) $=\mathrm{Fe}_{2} \mathrm{SiO}_{4}$ (fa) $+\mathrm{Mg}_{2} \mathrm{Si}_{2} \mathrm{O}_{6}$ (cenh), which is not included explicitly among our reactions, but appears implicitly since it is obtained by subtracting reaction 2 from reaction 1. Taking both our own database and that of Loucks (1996), we recalibrated the clinopyroxene and olivine models, treating $\mathrm{fo}+\mathrm{cfs}=\mathrm{fa}+\mathrm{cenh}$ as a single-reaction thermometer. The key changes made to the clinopyroxene model through this approach were to $\Delta G_{\text {cen }}^{\text {tran }}(P, T)$ and $\Delta G_{\text {cfs }}^{\text {tran }}(P, T)$, which were recalibrated while preserving their fit to the estimated transition curves in $P-T$ space [taken from Boyd et al. (1964), as interpreted by Gasparik (1990), for enstatite-clinoenstatite; and from Lindsley (1981), for ferrosilite-clinoferrosilite]. We also decreased the value of $\Delta G_{\mathrm{fmc}}^{\mathrm{od}}$ 
$(P, T)$ from -4.4 to $-6.5 \mathrm{~kJ} / \mathrm{mol}$. Minor adjustments were made to the relatively well-known interaction energies in the $\mathrm{CaO}-\mathrm{FeO}-$ $\mathrm{MgO}-\mathrm{SiO}_{2}$ system, $W_{\text {(di,cfs) }}, W_{\text {(di,fmc) }}, W_{\text {(cenh,cfs) }}$, and $W_{\text {(cfs,fmc), while }}$ respecting the experimental constraints placed on them (Turnock and Lindsley 1981; Lindsley 1983; see Green et al. 2016). The revised values are considered to be better constrained than the originals. The modified models continue to predict temperatures for the fo $+\mathrm{cfs}=\mathrm{fa}+$ cenh reaction with a large scatter, but now with a reasonable standard error of estimate of $\pm 71{ }^{\circ} \mathrm{C}$.

We made further adjustments to many of the less wellconstrained interaction energies, with reference to both the fo + $\mathrm{cfs}=\mathrm{fa}+$ cenh reaction and the results of av $P$ calculations on the experimental database. These adjustments involved reducing the size of the interaction energies by $\sim 40 \%$. In modifying the interaction energies, we treated them as falling into groups that should retain similar values: (1) the $W([\mathrm{cenh}, \mathrm{cfs}, \mathrm{fmc}],[\mathrm{jd}, \mathrm{acm}])$ parameters (notation indicates interaction energies between each of the end-members in the first brackets with each of the endmembers in the second); (2) the $W$ ([cenh,cfs,fmc],[cats]) parameters; (3) the $\mathrm{W}([\mathrm{jd}, \mathrm{acm}]$,[cats]) parameters. $W([\mathrm{di}]$,[cats]) was adjusted independently. These modifications greatly reduced the excessive average $P$ estimates for COlP (Fig. 5b), and removed the high residuals associated with $a_{\text {cats }}$ and $a_{\mathrm{jd}}$ when SCOIP is used. Furthermore, values of $\sigma_{\text {fit }}$ for the experiments typically decreased, with fewer experiments failing the $\chi^{2}$ test; this was a valuable indication that the adjustments tended to make the models, as a set, predict a more mutually consistent set of independent reactions given the experimental phase compositions.

Individual changes made to the poorly constrained interaction energies should not necessarily be regarded as improvements to the original $a-x$ relations, since average $P$ in general demands less accurate $a-x$ relations than the forward-modeling calculations for which the Green et al. (2016) clinopyroxene model was developed. However, it is interesting that a much less non-ideal model was required to produce good average $P$ results, especially considering that the pressure information in reactions $1-3$ is related primarily to formation of aluminous pyroxene from plagioclase (i.e., Ca-tschermak + Quartz $=$ Anorthite). The thermodynamics of the key pyroxene and plagioclase end-members in the Holland and Powell (2011) data set, including the crucial volumetric parameters, are expected to be well known.

Olivine. We initially followed Jennings and Holland (2015) in adopting a simple symmetric model for a forsterite-fayalite solid solution, with $\mathrm{Mg}-\mathrm{Fe}$ mixing on two identical $\mathrm{M}$ sites, as per Hackler and Wood (1989), with $W(\mathrm{fo}, \mathrm{fa})=8 \mathrm{~kJ} / \mathrm{mol}$. During refitting of the reaction fo $+\mathrm{cfs}=\mathrm{fa}+\mathrm{cenh}$, we found it necessary to introduce order-disorder, via an ordered end-member $\mathrm{Fe}^{\mathrm{M} 1} \mathrm{Mg}^{\mathrm{M} 2} \mathrm{SiO}_{4}$ (olfm; compare with discussion of ordered end-member fmc above; see also Supplementary ${ }^{2}$ Materials 3), with a Gibbs energy function given by $G_{\mathrm{olfm}}(P, T)=1 / 2\left[G_{\mathrm{fo}}(P, T)\right.$ $\left.+G_{\mathrm{fa}}(P, T)\right]+\Delta G_{\text {olf }}^{\text {od }}(P, T)$, and $\Delta G_{\text {olfm }}^{\text {od }}(P, T)=(-8+0.003 T+$ $0.02 P) \mathrm{kJ} / \mathrm{mol}$. This expression yields $-3.8 \mathrm{~kJ} / \mathrm{mol}$ at $1100{ }^{\circ} \mathrm{C}$ and $5 \mathrm{kbar}$, and remains negative, i.e., favoring ordering, below $2300{ }^{\circ} \mathrm{C}$ within the pressure range of interest. $\Delta G_{\text {olfm }}^{\text {od }}(P, T)$ is thus of a physically plausible size over the $P-T$ range of interest, comparable with $\Delta G_{\text {fmc }}^{\text {od }}(P, T)$. We stress, however, that our calibration does not provide unique constraints on the $\mathrm{a}, \mathrm{b}$, and c terms of $\Delta G_{\text {olfm }}^{\text {od }}(P, T)$ and they should be considered essen- tially as fit parameters, compensating for other difficulties in modeling Fe-Mg exchange between olivine and clinopyroxene in natural systems.

Spinel. Jennings and Holland (2015) used the spinel $a-x$ relations of Bryndzia and Wood (1990), in the system MgO-FeO$\mathrm{Fe}_{2} \mathrm{O}_{3}-\mathrm{Al}_{2} \mathrm{O}_{3}-\mathrm{Cr}_{2} \mathrm{O}_{3}$, in which all cations mix on three identical sites. Such a model greatly simplifies the mixing behavior of spinel, by neglecting cation and magnetic disordering. Nevertheless, Bryndzia and Wood (1990) applied it successfully to oxybarometry of spinel peridotites, and it performed convincingly in the forward calculations of Jennings and Holland (2015), also on peridotite. Therefore, we initially adopted the Bryndzia and Wood (1990) $a-x$ relations, extended to include $\mathrm{TiO}_{2}$ by T.J.B. Holland (personal communication; see Supplementary ${ }^{2}$ Material 3).

For the majority of experiments that contained magnetite rather than $\mathrm{Cr} / \mathrm{Al}$-spinel, we found that av $P$ calculations with SCOlP had a tendency to underestimate experimental pressures, even when calculations with COIP tended to overestimate them. Modifications to the clinopyroxene model, as described above, reduced $\bar{P}$ estimates for both assemblages. To overcome this discrepancy between the assemblages, and following the observation that the end-members sp and herc showed large uncertainty-normalized residuals in activity (as suggested by the av $P$ diagnostics), we were obliged to add large $\Delta G_{i}^{\bmod }(P, T)$ terms, of $5 \mathrm{~kJ} / \mathrm{mol}$, to the sp and herc end-members. These terms may be crudely compensating for the highly simplified form of the spinel $a-x$ relations, and indeed any unidentified weaknesses elsewhere in the set of thermodynamic models, that compensate for each other in CO1P. Additionally, we found that pressures for experiments containing $\mathrm{Cr} / \mathrm{Al}$-spinel were routinely overestimated. We were able to prevent this by adjusting the value of $\mathrm{W}_{\text {sp-picr }}$ from 39 to $23 \mathrm{~kJ} / \mathrm{mol}$, and that of $\mathrm{W}_{\text {herc-picr }}$ from 27 to 16 $\mathrm{kJ} / \mathrm{mol}$. The modifications also allowed most of the experiments to pass the $\chi^{2}$ test, whereas, using the original spinel model, most of SCOIP calculations failed, with $\sigma_{\text {fit }}>>1.49$.

\section{Inputs for av $P$ : Compositions, uncertainties, $P_{\mathbf{0}}$, and $T_{\mathbf{0}}$}

Mineral formulas for the SCO1P/CO1P phases in the experimental runs and natural samples were recalculated from the compositions determined by electron microprobe. Iron was assumed to be all ferrous in olivine and all ferric in plagioclase. $\mathrm{Fe}^{3+}$ in clinopyroxene and spinel was calculated from stoichiometry following the method of Droop (1987). Mineral formulas were then converted into compositional variables suitable for the $a-x$ relations (Supplementary ${ }^{2}$ Material 2). THERMOCALC (Powell and Holland 1988) version $3.47 \mathrm{i}$ was used to run the av $P$ algorithm on these data, generating a value of $\bar{P}$ based on each assemblage for each experiment. The results obtained from the av $P$ algorithm are sensitive to the relative size of uncertainties specified for the compositional variables, and also to those applied to the interaction energies, $W_{(m, n)}$, in the $a-x$ relations.

Since rigorous error propagation is not applicable to our experimental database (see Supplementary ${ }^{2}$ Material 4), uncertainties on most of the compositional variables for the experimental samples have been simply set to $\pm 0.01 \mathrm{apfu}$, a default value typically adopted in average $P$ (Powell and Holland 2008). Given the difficulty of quantifying realistic uncertainties on the spinel $a-x$ model, which does not account for cation ordering, uncertainties 

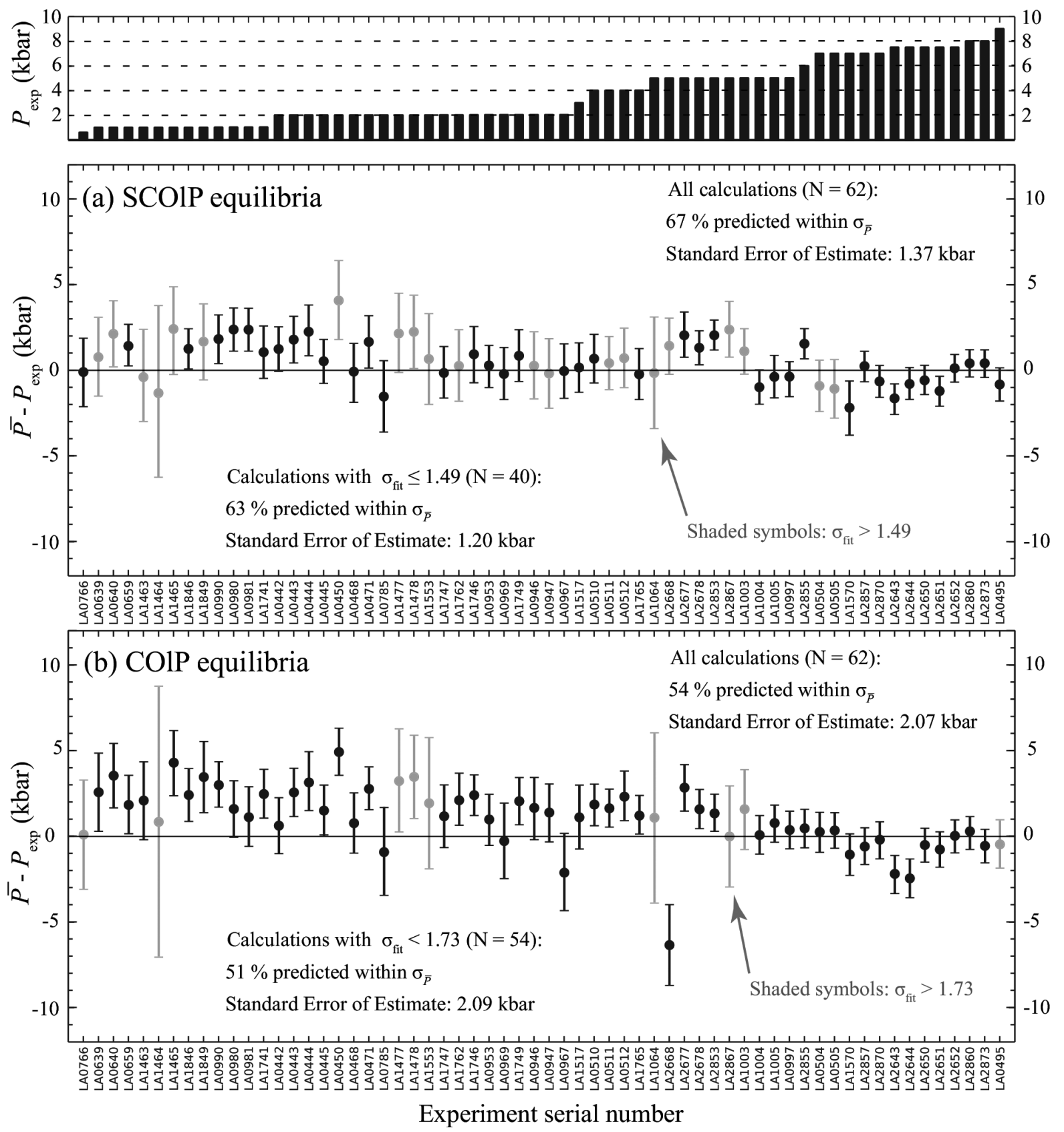

FIGURE 5. Results of av $P$ calculations on the refined database of experiments containing the subset SCOlP in their run products. Calculations have been performed with either (a) SCOlP equilibria (i.e., 6 reactions) or (b) COlP equilibria (3 reactions), using the thermodynamic model refined in this work. Error bars are $\sigma_{\bar{P}}$ (see text). The labels on the x-axes are the experiment index numbers, ordered as in the Supplementary Material ${ }^{2}$ 1 (i.e., increasing $P_{\text {exp }}$ ).

on $x^{\text {sp }}\left[\mathrm{Fe}^{2+} /\left(\mathrm{Fe}^{2+}+\mathrm{Mg}\right)\right]$ and $f^{\text {sp }}\left[\mathrm{Fe}^{3+}\right]$ have been set to $0.04 \mathrm{apfu}$, with the aim of accounting for the possible oversimplification of spinel $a-x$ relations. This simplified set of compositional uncertainties was then compared with the true uncertainties, derived from partial error propagation, during trial calculations on the refined experimental database using SCOIP equilibria. No significant difference was found in the results. In this test, we also noted that the maximum variations of $\bar{P}$ between different uncertainties assumptions are on the order of $\sigma_{\bar{P}}$, as suggested by Powell and Holland (2008).

For the natural samples, the mineral compositions used for thermobarometry are taken from individual spot analyses of adjacent crystal rims, since adjacent rims are assumed to most closely represent the equilibrium assemblage. The compositional errors are initially derived from counting statistics of the electron microprobe (Supplementary ${ }^{2}$ Table 5). Given that such errors 
are small and weakly correlated, partial error propagation is assumed to yield sufficiently realistic uncertainties for most of the $a-x$ model compositional variables. However, after applying the partial error, uncertainties on compositional variables $x^{\mathrm{sp}}$ and $f^{\mathrm{sp}}$ (Supplementary ${ }^{2}$ Material 2) have been increased by a factor of 4 , consistent with the modifications adopted for the experimental samples described above.

By default, in THERMOCALC uncertainties on the interaction energies are set to $\pm 2 \mathrm{~kJ} / \mathrm{mol}$ (Powell and Holland 2008). For the $a-x$ models used here, uncertainties on many interaction energies are not well constrained and therefore we chose initially to retain this approximation during the assessment of av $P$ calculations on the experimental database. Once the final set of modified $a-x$ models had been selected, we noted that av $P$ calculations produced low $\sigma_{\text {fit }}(<<1.0)$ for many experimental runs and natural samples, implying that the overall input uncertainties were in many cases excessive. We therefore reduced the uncertainties on interaction energies to $\pm 1 \mathrm{~kJ} / \mathrm{mol}$, which increased to $\sigma_{\text {fit }}$ values generally closer to 1.0 (Supplementary ${ }^{2}$ Material 1 and Table 3 ) and decreased $\sigma_{\bar{P}}$ by about 0.2 kbar. Such generalized uncertainties on interaction energies were adopted as they represent the best compromise to simultaneously obtain low $\sigma_{\bar{P}}$ and successfully prediction of experimental pressures. In fact, this might be a realistic estimate of the uncertainties on the most critical parameters, but many of the less influential parameters are much less well known.

During av $P$ calculations applied to experimental samples, the values of $P_{0}$ and $T_{0}$ were set to $T_{\exp }$ and $P_{\exp }$ (we note that uncertainties in the measured pressure and temperature of the experimental runs can be as high as $\pm 0.5 \mathrm{kbar}$ and $\pm 20{ }^{\circ} \mathrm{C}$ ). In the case of natural samples, $P_{0}$ was set to $4 \mathrm{kbar}$, representing the middle of the range of crustal pressure. For both experimental and natural samples, the window within which the average $P$ algorithm should search for the $P_{r}$ values was set to $P_{0} \pm 20$ kbar. Methods for choosing $T_{0}$ for natural samples are discussed in a later section.

\section{AVP CALCULATIONS ON THE EXPERIMENTAL DATABASE}

In this section, we report the results of av $P$ calculations on the experimental database using the refined thermodynamic models and the associated uncertainties adopted in this work.

\section{AvP output: $\bar{P}, \sigma_{\bar{P}}$, and $\sigma_{\text {fit }}$}

Spinel + clinopyroxene + olivine + plagioclase equilibria (SCOIP). The results of calculations using SCOIP on the 62 experimental samples are good, as shown in Figure 5a (see also Supplementary ${ }^{2}$ Material 1). $65 \%$ of the calculations passed the $\chi^{2}$ test (i.e., $\sigma_{\text {fit }}<1.49$ ), which indicates that the experimental mineral compositions and the thermodynamic data, with their associated uncertainties, can be safely combined in the averaging procedure. Slightly higher $\sigma_{\text {fit }}$ values (no more than $20 \%$ higher than the cut-off imposed by the $\chi^{2}$ test) might still be considered acceptable, especially since $\sigma_{\bar{P}}$ is increased by a factor equal to $\sigma_{\text {fit }}$ when the $\chi^{2}$ test is failed. This would increase the proportion of acceptable calculations to $82 \%$. For the calculations that passed the $\chi^{2}$ test, $\sigma_{\bar{P}}$ varies between 0.80 and $2.10 \mathrm{kbar}$, with a mean value of $1.24 \mathrm{kbar}$. Considering all the calculations, the experimental pressures are predicted within $\sigma_{\bar{P}}$ for $67 \%$ of the samples, consistent with the expectation that the interval $\bar{P} \pm \sigma_{\bar{P}}$ will encompass the experimental pressure $68 \%$ of the time. The accuracy of average $P$ can also be demonstrated by calculating SEE for $\bar{P}$. For the selected experimental data set the calculated $\bar{P}$ yields a SEE of $\pm 1.37 \mathrm{kbar}( \pm 1.20$ kbar considering only calculations with $\chi^{2}$ test passed), which is small relative to the typical values obtained by the existing geobarometers for gabbroic assemblages. For example, the clinopyroxene-orthopyroxene barometer of Putirka (2008) (his Eq. 39) has SEE $= \pm 2.8 \mathrm{kbar}$ using his experimental database and $\mathrm{SEE}= \pm 2.7 \mathrm{kbar}$ using our filtered experimental database (see Supplementary ${ }^{2}$ Material 1) in the $P$ range $0.5-10$ kbar.

No dependence of the pressure residuals $\Delta P\left(\bar{P}-P_{\exp }\right)$ on $P_{\exp }$ (Fig. 5a) or $T_{\exp }$ (Fig. 6a) is observed, suggesting that the $P$ - and $T$-dependency of the adopted $a-x$ relations is appropriate for the purpose of av $P$ calculations. Furthermore, the residuals are not dependent on the composition of plagioclase $(\mathrm{An}=25-94$ mol $\%)$, olivine $(\mathrm{Fo}=61-95 \mathrm{~mol} \%)$ or spinel $\left(\mathrm{Fe}^{3+} /\left[\mathrm{Fe}^{3+}+\mathrm{Al}+\mathrm{Cr}\right]\right.$ $=0.00-0.90$; Fig. 6b). For clinopyroxene, the residuals do not appear to vary with composition, although a slight dependence of $\sigma_{\bar{P}}$ with mg\# might be inferred (Fig. 6c), given the apparent higher values of $\sigma_{\bar{P}}$ when $\mathrm{mg} \#<0.80$. No correlations or systematic deviations in $\Delta P$ are observed between hydrous and

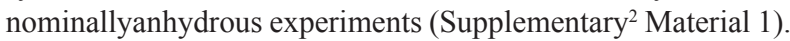
Overall, the application of average $P$ to SCO1P with the adopted thermodynamic model produces satisfactory results for a wide range of experimental compositions, and can therefore be applied with confidence to natural mafic and ultramafic rocks that contain spinel, clinopyroxene, olivine, and plagioclase. More accurate $\mathrm{Fe}^{3+} / \Sigma \mathrm{Fe}$ estimations for clinopyroxene and spinel would likely increase the accuracy of the calculated pressures. However, the good av $P$ results obtained in our calculations suggest that the errors related to $\mathrm{Fe}^{3+}$ calculated from stoichiometry do not generally have a significant deleterious effect on $\bar{P}$.

Clinopyroxene + olivine + plagioclase equilibria (COIP). Figure $5 \mathrm{~b}$ shows the results of av $P$ calculations with COlP equilibria on the same experimental data set used for SCOIP. Most of the calculations passed the $\chi^{2}$ test $\left(\sigma_{\text {fit }}<1.73\right)$ and $\sigma_{\bar{P}}$ varies between 0.93 and $3.20 \mathrm{kbar}$. Results for samples at $P_{\exp } \geq$ 5 kbar show a good agreement with the experimental pressures and low calculated uncertainties (Fig. 5b). However, pressures are overall predicted within the uncertainties for a smaller proportion of experiments (54\%), which is linked to a systematic overestimation of $\sim 1.5 \mathrm{kbar}$ for samples equilibrated at $P_{\exp }<5$ kbar. Comparable results were obtained on the entire data set of 209 experiments containing CO1P (Supplementary ${ }^{2}$ Material 6). We suspect that the source of the overestimation at lower pressures could be an excess amount of $\mathrm{Al}^{\mathrm{IV}}$ in clinopyroxene related to growth rate (Mollo et al. 2010), which is expected to have a relatively larger effect where equilibrium values for $\mathrm{Al}^{\mathrm{IV}}$ are low, i.e., at low pressures. This issue does not significantly influence the accuracy of $\bar{P}$ when reactions involving spinel end-members are included in the independent set (i.e., SCOIP).

\section{AvP output: Residuals and correlations}

In this section, we examine the results of the least-squares minimization for the individual end-members involved in the reactions and the correlation between the six SCOIP reactions. 

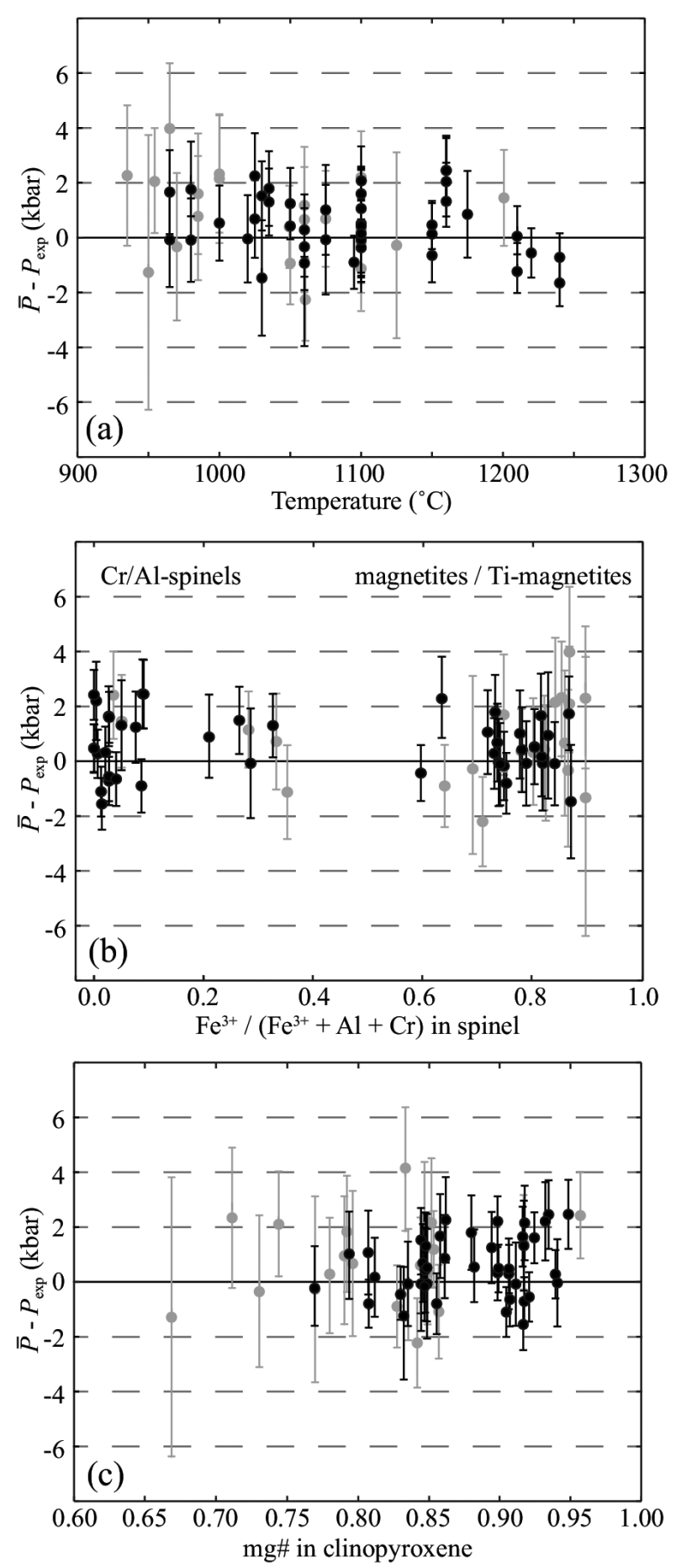

FIGURE 6. Residuals in calculated $\bar{P}$ relative to $P_{\text {exp }}$, for SCOlP equilibria, plotted vs. (a) $T_{\text {exp }}$, (b) spinel $\mathrm{Fe}^{3+} /\left[\mathrm{Fe}^{3+}+\mathrm{Al}+\mathrm{Cr}\right]$, and (c) clinopyroxene mg\#. Data set and symbols as in Figure 5.

The low- $\sigma_{\text {fit }}$ values obtained for most of the calculations on the experimental database indicate that, in general, the calculated end-member activities and enthalpies do not have to be adjusted outside their uncertainties to obtain a consistent value of $P$ (i.e., $\bar{P})$ for the six reactions. In the average $P$ diagnostics this is shown by the low uncertainty-normalized residuals in $\log$ (activity) $\left(e_{i}^{*}\right)$ and the enthalpy $\left(H_{i}^{*}\right)$ for each end-member $i$ (see Supplementary $^{2}$ Material 2). For calculations that passed the $\chi^{2}$ test, $\left|e_{i}^{*}\right|$ is always $<2.5$ and $\left|H_{i}^{*}\right|$ is always $<1.0$ for all end-members. No systematic outliers appear for the calculations on different samples, with both $e_{i}^{*}$ and $H_{i}^{*}$ scattering randomly around zero. The only exception is for the end-member acmite, which shows $e_{i}^{*}$ varying between -0.1 and 2.5 and $H_{i}^{*}$ between -0.2 and 1.4 Possibly, such systematic positive residuals indicate a slight systematic overestimation of $\mathrm{Fe}^{3+}$ in clinopyroxene as determined by stoichiometry. For calculations that did not pass the $\chi^{2}$ test no end-member is identifiable that systematically shows high residuals (i.e., $\left|e_{i}^{*}\right|>2.5$ and $\left|H_{i}^{*}\right|>1.0$ ). The diagnostic $h_{\mathrm{i}}$ (see Supplementary ${ }^{2}$ Material 2) shows that for most of the experimental samples no single end-member has a prevailing influence on the calculated $\bar{P}$. The end-members that are most likely to be influential are cats, cenh, sp, herc, and jd. However, in a typical calculation such as that illustrated in the Supplementary ${ }^{2}$ Material 2, if the uncertainty on $\ln a_{i}$ of any single end-member $i$ is doubled, the value of $\bar{P}$ changes by $\leq 0.2 \mathrm{kbar}$, except in the case of cats for which it is reduced by 0.4 kbar.

Supplementary ${ }^{2}$ Material 7 shows the correlation matrixes of the enthalpies of reactions $\left(\Delta H_{\mathrm{r}}\right), \ln K_{\mathrm{r}}$, and $P_{\mathrm{r}}$, for the calculations on the experimental database. The matrix of $\Delta H_{\mathrm{r}}$ values is the same in each calculation. $\Delta H_{\mathrm{r}}$ values for the reaction pairs reactions $1-4(0.729)$, reactions $2-4(0.746)$, and reactions $3-5$ $(0.741)$ are particularly highly correlated due to their shared end-members. These reaction pairs also show relatively highly correlated values of $\ln K_{\mathrm{r}}$, but the magnitude of the correlations in $\ln K_{\mathrm{r}}$, and consequently in $P_{\mathrm{r}}$, are strongly dependent on phase compositions. In a calculation for which $P_{\mathrm{r} 3}$ and $P_{\mathrm{r} 5}$ have a correlation coefficient of 0.99 , these two reactions amount to a single independent constraint on how the end-member properties should be adjusted to attain a consistent $\bar{P}$. However, in calculations involving other phase compositions these reactions show only weak to moderate correlation.

\section{Sensitivity of $\operatorname{Av} P$ to $P_{0}$ and $T_{0}$}

Calculations with av $P$ require an initial estimate of pressure $\left(P_{0}\right)$ and temperature $\left(T_{0}\right)$ to be specified. These are needed for the initial calculation of end-member enthalpies and activities. We performed a test to investigate how different assumptions about $P_{0}$ and $T_{0}$ may influence the calculated SCOIP equilibria and the subsequent results of average $P$. Multiple calculations with average $P$ on the selected experiments have been performed, first varying $P_{0}$ in the range $0-15 \mathrm{kbar}$ (with $T_{0}=T_{\text {exp }}$ ) and then varying $T_{0}$ in the range $600-1400{ }^{\circ} \mathrm{C}$ (with $P_{0}=P_{\text {exp }}$ ). The first tests showed a negligible effect of $P_{0}$ on the calculated pressure. For the sample $\operatorname{ShR} 658\left(P_{\exp }=2.0 \mathrm{kbar}, T_{\exp }=1075^{\circ} \mathrm{C}\right.$; Supplementary $^{2}$ Material 1), for example, a substantial difference of 15 kbar in $P_{0}$ produces a difference in the calculated $\bar{P}$ of $0.01 \mathrm{kbar}$ $\left(\bar{P}=2.94 \pm 1.62 \mathrm{kbar}\right.$ if $P_{0}=0 \mathrm{kbar} ; \bar{P}=2.95 \pm 1.62 \mathrm{kbar}$ if $P_{0}$ $=15 \mathrm{kbar}$ ), with no difference in the quality of the fit. Similar results have been observed for other experimental samples in the data set.

On the other hand, different assumptions about $T_{0}$ variably affect the calculated $\bar{P}$. An example is reported in Figure 7, which shows the results for the same experiment ShR658. In this case, 
the temperature dependence of $\bar{P}, d \bar{P} / d T_{0}$, corresponds to -0.012 $\mathrm{kbar} /{ }^{\circ} \mathrm{C}$. More generally the test on the experimental data set showed that $d \bar{P} / d T_{0}$ is always negative. Furthermore, the absolute value of the dependence of $\bar{P}$ on $T_{0}$ is smaller for greater values of $\bar{P}$, with $d \bar{P} / d T_{0}$ varying from -0.016 to $-0.002 \mathrm{kbar} /{ }^{\circ} \mathrm{C}$ (Fig. 8 ). This indicates that, for natural assemblages equilibrated at high pressures, even errors related to crude temperature estimates (e.g., from geological/petrological inferences) will not significantly increase the uncertainty on the calculated pressure (i.e., additional $\pm 0.4-0.6 \mathrm{kbar}$ for errors on $T_{0}$ on the order $\pm 150-200{ }^{\circ} \mathrm{C}$ ).

For assemblages equilibrated at relatively low pressures $(<5$ kbar), uncertainties on $T_{0}$ on the order of $150-200{ }^{\circ} \mathrm{C}$ might increase the total pressure uncertainties by $1.5-2.5 \mathrm{kbar}$, which indicates the need of reliable methods to estimate equilibration temperature when applying average $P$ to natural samples. One such a method is to carry out the average $P$ procedure at multiple temperatures, and observe the variation in the value of $\sigma_{\text {fit }}$. If the variation of $\sigma_{\text {fit }}$ with $T_{0}$ follows a polynomial function of the type $\sigma_{\text {fit }}=\mathrm{a}^{\prime} T_{0}^{2}+\mathrm{b}^{\prime} T_{0}+\mathrm{c}^{\prime}$ (where $\mathrm{a}^{\prime}, \mathrm{b}^{\prime}$, and $\mathrm{c}^{\prime}$ are constants and $a^{\prime}>0, b^{\prime}<0$ ), and a minimum of $\sigma_{\text {fit }}$ is clearly identifiable (e.g., Fig. 7), then the value of $T_{0}$ that gives the minimum value of $\sigma_{\text {fit }}$ can be considered to give better estimates of $T$. Figure 7 shows a successful example of such a method, in which the estimated temperature $\left(T \sigma_{\text {fit }} ; 1050{ }^{\circ} \mathrm{C}\right)$ is close to the measured experimental temperature, $T_{\text {exp }}\left(1075^{\circ} \mathrm{C}\right)$. We applied such a method to the selected experimental data set, first to evaluate the reliability of the estimated temperatures and second to assess how the possible errors associated with these estimates affect the calculated $\bar{P}$. For some experiments, the variation of $\sigma_{\text {fit }}$ with $T_{0}$ is such that a minimum in $\sigma_{\mathrm{fit}}$ cannot be identified and therefore these experiments $(n=25)$ have been removed from the test data set. The results of the test are reported in Figure 9, which shows that $T \sigma_{\text {fit }}$ predicts the experimental temperatures with a SEE of $\pm 93{ }^{\circ} \mathrm{C}(\mathrm{n}=37)$. Application of av $P$ to the same experimental data set, adopting $T_{0}=T \sigma_{\text {fit }}$ instead of $T_{0}=T_{\text {exp }}$, still produces acceptable calculated pressures (cf. Figs. $9 \mathrm{~b}$ and $9 \mathrm{~d}$ ).

We note that $\sigma_{\bar{P}}$ also varies with $T_{0}$, and the minima in $\sigma_{\bar{P}}$ and $\sigma_{\text {fit }}$ do not generally occur at the same $T_{0}$. This suggests that temperature is not strongly constrained in the sample. We find empirically that the optimal $T_{0}$ is usually better predicted by the minimum in $\sigma_{\text {fit }}$, even when $\sigma_{\text {fit }}$ passes the $\chi^{2}$ test over a wide range of temperatures. The use of $T_{\mathrm{\sigma}_{\mathrm{fit}}}$ as a possible $T$ estimate can be justified in that $\sigma_{\text {fit }}$ characterizes the compatibility of the different independent reactions, and $T_{0}$ contributes to the formulation of those reactions without being formally included in the covariance matrix summarized by $\sigma_{\bar{P}}$.

In conclusion, $P_{0}$ does not have significant effects on the calculated $\bar{P}$ at any condition and therefore we suggest the initial estimate to be always set to $4 \mathrm{kbar}$ (i.e., mid-crustal values). On the other hand, the effect of $T_{0}$ might be in some cases significant, but it can be easily evaluated for each sample by running multiple av $P$ calculations at different $T_{0}$. If no other thermometer can be applied that gives $T$ uncertainties $<90{ }^{\circ} \mathrm{C}$, then $T_{0}=T_{\text {ofit }}$ can be used to produce the best estimate of $P$.

\section{APPLICATION TO NATURAL ROCKS}

Given the success of tests on the experimental data set, we next applied the refined thermodynamic models to estimating

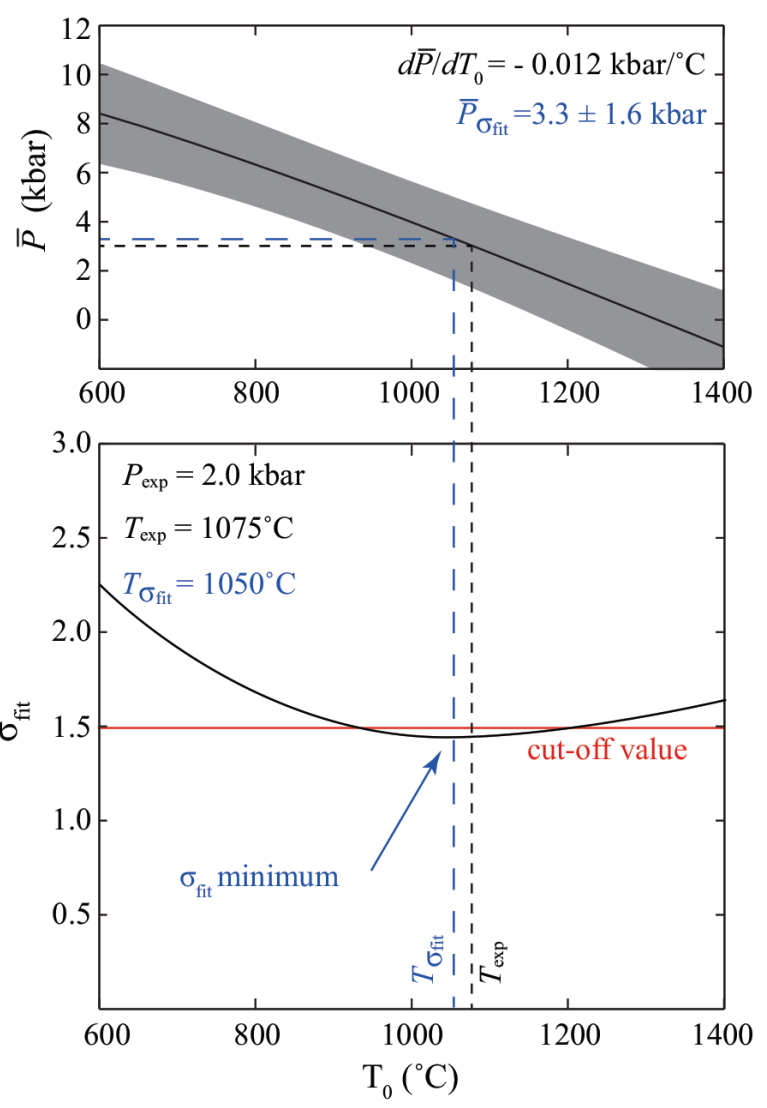

FigURE 7. Results of multiple av $P$ calculations at different temperatures $T_{0}$ for the experimental sample ShR658 (Husen et al. 2016). $P_{0}=P_{\exp }$ for all the calculations. The temperature dependence of the calculated pressure $\left(d \bar{P} / d T_{0}\right)$ for this sample is indicated in the top box. $T \sigma_{\text {fit }}$ is the value of $T_{0}$ that produces the avP result with the lowest $\sigma_{\text {fit }}$ $\left(\bar{P} \sigma_{\text {fit }}\right)$. Note, with reference to the uncertainty envelope (gray envelope in the top box), that outside the $T$ range in which the $\chi^{2}$ test is passed, the uncertainty is multiplied by $\sigma_{\text {fit }}$. (Color online.)

the pressure of formation of igneous rocks, choosing samples containing spinel, clinopyroxene, olivine, and plagioclase. We carefully selected two groups of mafic/ultramafic xenoliths with texture, mineralogy, and mineral chemistry suggesting good attainment of chemical equilibrium. Compositions of minerals in these natural samples are reported in Figure 2. The first group of xenoliths, from the island of Dominica, Lesser Antilles, provides an example of the application of av $P$ to gabbroic rocks from a mid-upper island arc crust. The second group, which was described and analyzed by McGuire (1994) and McGuire and Mukasa (1997), is from the Wikieup volcanic field, Arizona, and provides an example of gabbroic and ultramafic xenoliths from the lower continental crust. Unless otherwise specified, the following discussion refers to calculations with SCOIP.

\section{Gabbroic xenoliths from Dominica, Lesser Antilles}

Background, sample description, and analyses. The Lesser Antilles is an active volcanic arc resulting from westward subduction of the South American plate beneath the Caribbean plate (Macdonald et al. 2000). The volcanic products, which 


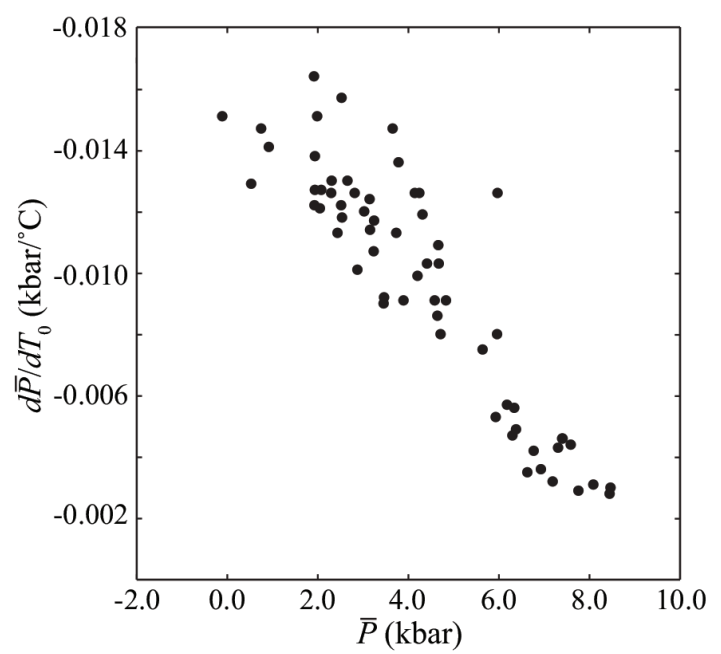

FigURE 8. Temperature dependence of av $P\left(d \bar{P} / d T_{0}\right)$ plotted vs. calculated pressures (at $T_{0}=T_{\text {exp }}$ ), for the selected experimental data set used in this work. The higher the calculated value of $\bar{P}$, the less sensitive this value is to the choice of $T_{0}$.

vary from basalts to andesites and dacites, host a large number of plutonic xenoliths showing various mineralogical compositions (Arculus and Wills 1980; Tollan et al. 2012; Stamper et al. 2014b; Cooper et al. 2016). The ubiquity of these xenoliths provides an exceptional opportunity to investigate the nature of the crust and the evolution of magmatic systems in an island arc setting, but such an investigation requires precise estimates of the pressure of formation of the xenoliths. Given that the estimated thickness of the crust in the Lesser Antilles varies between 25 and $35 \mathrm{~km}$ (cf. Boynton et al. 1979; Christeson et al. 2008; Kopp et al. 2011), the gabbroic xenoliths are likely to have equilibrated at pressures between $\sim 1$ and $\sim 8 \mathrm{kbar}$. Therefore, only geobarometric estimates with low associated uncertainties $(<2 \mathrm{kbar})$ can provide useful insight into the vertical distribution of mafic lithologies in the crust.

Dominica, in the center of the arc, is mainly composed of Pliocene to recent volcanic rocks (Lindsay et al. 2005; Howe et al. 2015). Plutonic xenoliths, mostly consisting of gabbroic assemblages with or without olivine, orthopyroxene, and hornblende, have been found as clasts in young, reworked sediments from the southern part of the island. For the purpose of testing the applicability of the av $P$ method, we selected three xenoliths containing the assemblage SCOIP, which have been collected from marine deposits close to the village of Petite Savanne (southern Dominica), on the edge of the Foundland volcanic center. A schematic description of these samples, highlighting the main textural and mineralogical features, is shown in Supplementary ${ }^{2}$ Material 8. Note that xenolith DC93 is composed of two parts (a coarse-grained troctolite, DC93a, attached to a heterogranular Ol-gabbronorite, DC93b).

Details of electron microprobe analyses and results are reported in the Supplementary ${ }^{2}$ Material 5. Compositions of olivine, spinel, clinopyroxene, and plagioclase (Fig. 2) are similar to those found in other cumulate xenoliths from the Lesser Antilles (e.g., Tollan et al. 2012; Stamper et al. 2014b; Cooper et al. 2016).
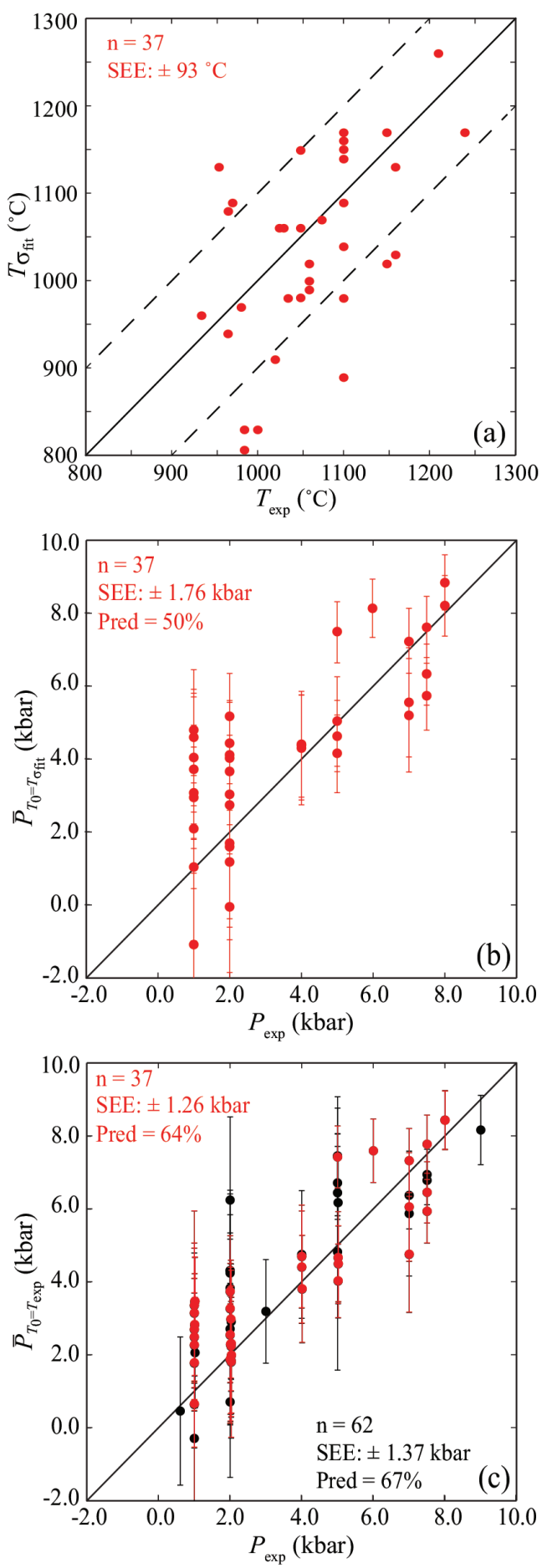

FIGURE 9. Temperature estimates derived by minimizing $\sigma_{\text {fit }}\left(T \sigma_{\text {fit }}\right)$ for the experimental data set and their effect on the calculated $\bar{P}$. (a) Comparison between $T \sigma_{\text {fit }}$ and the true temperature $T_{\text {exp. }}$. (b,c) Test of $\bar{P} \pm$ $\sigma_{\bar{P}}$ calculated using either (b) $T_{0}=T \sigma_{\text {fit }}$ or $(\mathbf{c}) T_{0}=T_{\text {exp }}$. In $\mathbf{c}$, experiments shown in black are those for which $T \sigma_{\text {fit }}$ cannot be estimated, as no minimum in $\sigma_{\text {fit }}$ as a function of $T_{0}$ can be identified. In all cases $P_{0}=$ $P_{\text {exp. }}$. SEE $=$ Standard error of estimate; Pred $=$ percentage of calculations that predict $P_{\exp }$ within $\sigma_{\bar{P}}$. (Color online.) 
Coexisting olivine and plagioclase show relatively low-forsterite contents (68-73 mol\% Fo) and high-anorthite contents (87-93 mol\% An), respectively; clinopyroxenes are augites showing a limited range of mg\# (78-82\%); spinels are titanomagnetites with $\mathrm{TiO}_{2}$ contents of 7.6 to $9.2 \mathrm{wt} \%$. Grain-to-grain and corerim variations for olivine, spinel, pyroxenes, and plagioclase are small, suggestive of well-equilibrated assemblages. The largest compositional variations are observed in samples DC91 and DC93b (e.g., $\mathrm{Al}_{2} \mathrm{O}_{3}^{\mathrm{Cpx}}=1.9-3.7 \mathrm{wt} \%$ for DC91). Clinopyroxene in DC93b shows a poikilitic texture with anhedral spinel inclusions and a slight patchy zoning mainly limited to $\mathrm{Al}^{\mathrm{IV}}$ (0.07-0.13 apfu) and $\mathrm{Fe}^{3+}(0.03-0.04 \mathrm{apfu})$. For the purpose of thermobarometry, only the compositions of adjacent crystal rims have been used (Fig. 10).

AvP calculations. Mineral compositions reported in Supplementary ${ }^{2}$ Material 5 have been used to calculate $\bar{P}$, adopting the thermodynamic models and calculation methods described above (see also Supplementary ${ }^{2}$ Material 2 for the example of an av $P$ calculation on sample DC90). $T_{0}$ has been estimated by running a calculation every $10{ }^{\circ} \mathrm{C}$ in the range $700-1200{ }^{\circ} \mathrm{C}$, and selecting the temperature that produce the lowest $\sigma_{\text {fit }}\left(T \sigma_{\text {fit }}\right)$ (see above and Fig. 7). Temperatures calculated with this method $\left(870-1000{ }^{\circ} \mathrm{C}\right)$ and results of av $P$ calculations are reported in Table 3. All calculations produced low- $\sigma_{\text {fit }}$ values $(0.81-1.54)$ and $\sigma_{\bar{P}}$ values for each sample are low $(0.91-1.55 \mathrm{kbar})$. The lowest $\sigma_{\bar{P}}$ is obtained for the Ol-gabbronorite DC90 $(\bar{P}=3.58 \pm$ $0.91 \mathrm{kbar})$, which is the sample with the smallest compositional heterogeneities and best-equilibrated texture (e.g., $\sim 120^{\circ}$ grain boundaries). The Cpx-Amph-gabbronorite DC91 contains also minor orthopyroxene, which allowed for application of CpxOpx thermometry (Putirka 2008; Table 3). T estimated with this method is in agreement with $T \sigma_{\text {fit }}\left(896\right.$ vs. $\left.910{ }^{\circ} \mathrm{C}\right)$, although the observed $K_{\mathrm{D}}(\mathrm{Fe}-\mathrm{Mg})^{\mathrm{Cpx}-\mathrm{Opx}}$ is below the range considered by Putirka (2008) to demonstrate equilibrium (i.e., 0.79 vs. $1.09 \pm$ 0.14 ). Pressure estimated for this sample (at $T_{0}=T \sigma_{\text {fit }}$ ) is $1.94 \pm$ 1.09 kbar. For all four Dominica samples, uncertainty-normalized residuals are low $\left(\left|e_{a c m}^{*}\right|<1.5,\left|H_{a c m}^{*}\right|<0.27\right)$, with acmite showing somewhat higher values $\left(\left|e_{a c m}^{*}\right|<2.1,\left|H_{a c m}^{*}\right|<0.87\right)$, as observed for the calculations on the experimental database. End-members cats, cenh, and jd show the highest, but still acceptable, $h_{\mathrm{i}}$ values $\left(h_{\text {cats }}=0.26-0.30, h_{\text {cenh }}=0.12-0.18, h_{\text {jd }}=0.29-0.35\right)$. Calculations with COlP produced comparable pressure estimates and uncertainties, although $\bar{P}$ is systematically higher (by $\leq 1 \mathrm{kbar}$, Table 3), as previously observed in tests on the experimental
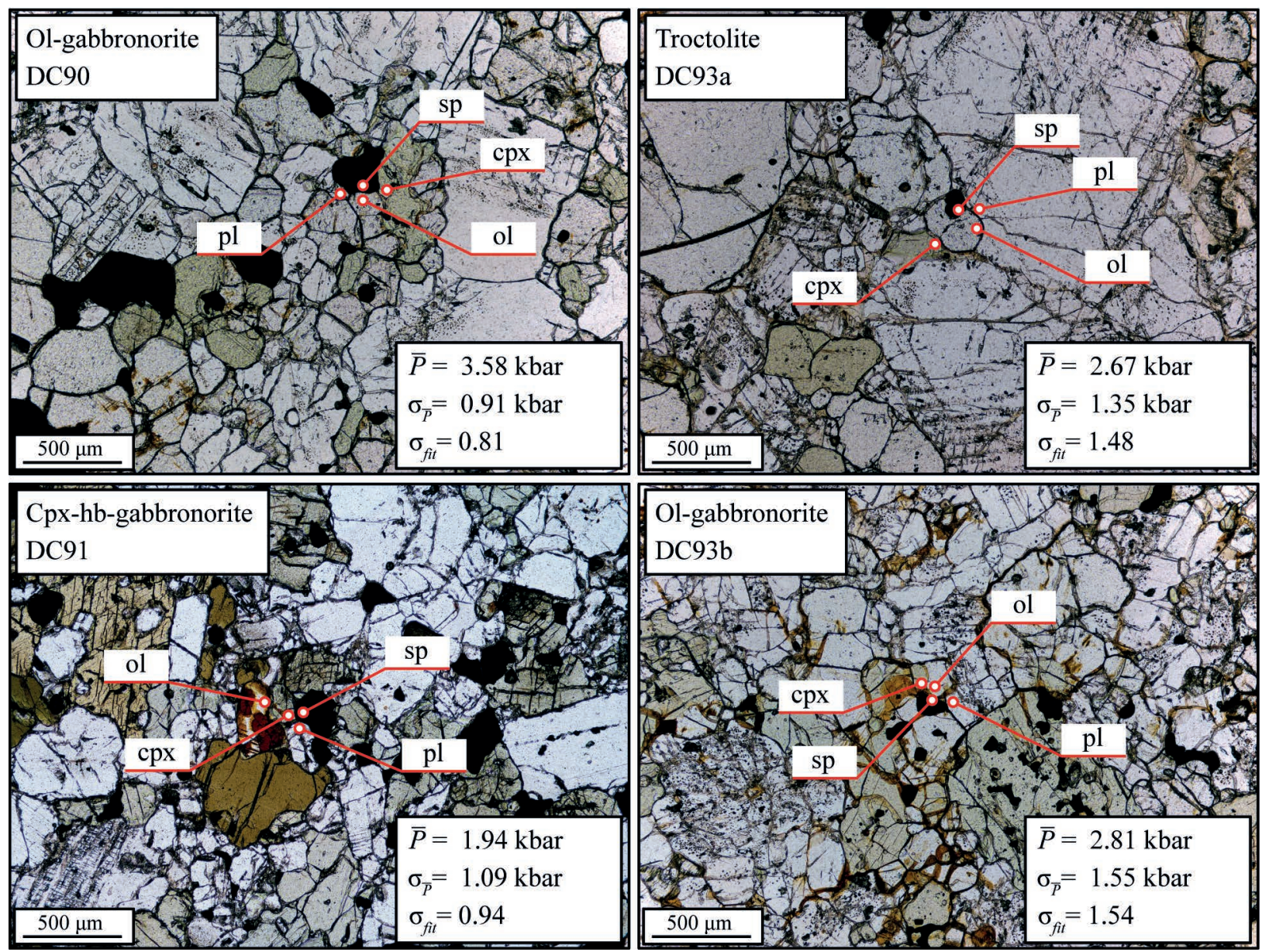

FIGURE 10. Photomicrographs (plane-polarized light) of the selected xenoliths from Dominica, with locations of the microprobe analyses used for av $P$ calculations. Results of av $P$ calculations with SCOlP equilibria are also reported in the boxes at the bottom-left corners. (Color online.) 
TABLE 3. Results of av $P$ calculations for the xenoliths from Dominica and Wikieup

\begin{tabular}{|c|c|c|c|c|c|c|c|c|c|}
\hline \multirow[b]{2}{*}{ Sample } & \multirow[b]{2}{*}{$\begin{array}{c}T_{\text {Cpx-opx }} \\
\left({ }^{\circ} \mathrm{C}\right)\end{array}$} & \multirow[b]{2}{*}{$\begin{array}{l}T \sigma_{\text {fit }} \\
\left({ }^{\circ} \mathrm{C}\right) \\
\end{array}$} & \multicolumn{3}{|c|}{ SCOIP equilibria } & \multirow[b]{2}{*}{$\begin{array}{c}\text { Depth } \\
(\mathrm{km})\end{array}$} & \multicolumn{3}{|c|}{ COIP equilibria } \\
\hline & & & $\begin{array}{c}\bar{P} \\
\text { kbar }\end{array}$ & $\begin{array}{c}\sigma_{\bar{P}} \\
\text { kbar }\end{array}$ & $\overline{\sigma_{\text {fit }}}$ & & $\begin{array}{c}\bar{P} \\
\text { kbar }\end{array}$ & $\begin{array}{c}\sigma_{P}^{-} \\
\text {kbar }\end{array}$ & $\sigma_{\text {fit }}$ \\
\hline \multicolumn{10}{|c|}{ Dominica } \\
\hline DC90 & - & 870 & 3.58 & 0.91 & 0.81 & $13.0 \pm 3.3$ & 4.21 & 0.98 & 0.36 \\
\hline DC91 & 896 & 910 & 1.94 & 1.09 & 0.94 & $7.1 \pm 4.0$ & 2.81 & 1.23 & 0.40 \\
\hline DC93a & - & 980 & 2.67 & 1.35 & 1.48 & $9.7 \pm$ & 3.66 & 0.97 & 0.92 \\
\hline DC93b & - & 1000 & 2.81 & 1.55 & 1.54 & 10.2 & 3.76 & 1.41 & 1.31 \\
\hline \multicolumn{10}{|c|}{ Wikieup } \\
\hline WK2-9 & 887 & 940 & 6.53 & 0.97 & 0.40 & $23.8 \pm 3.5$ & 6.55 & 0.99 & 0.54 \\
\hline WK2-49a & - & 1000 & 6.20 & 1.00 & 0.74 & $22.6 \pm 3.6$ & 6.19 & 1.20 & 1.17 \\
\hline WK1-24 & - & 1150 & 6.54 & 0.95 & 0.55 & $23.8 \pm 3.5$ & 6.46 & 0.99 & 0.84 \\
\hline WK1-63 & 953 & 1150 & 6.88 & 0.97 & 0.48 & $25.0 \pm 3.5$ & 6.86 & 1.00 & 0.73 \\
\hline
\end{tabular}

Notes: For all the calculations, $P_{0}=4.0 \mathrm{kbar}$ and $T_{0}=T \sigma_{\text {fit. }}$ Uncertainties on compositional variables have been propagated from analytical errors, with the corrections adopted in this work (see Supplementary ${ }^{2}$ Material 5). $T_{\text {cpx-opx }}$ refers to temperature calculated using Equation 37 in Putirka (2008). Depths of the xenoliths have been calculated from the estimated pressures, assuming an average density $(\bar{\rho})$ of the overlying crust of $2800 \mathrm{~g} / \mathrm{cm}^{3}$.

database at $P_{\exp }<5 \mathrm{kbar}$.

The composite xenolith DC93 contains two assemblages (DC93a, DC93b; Supplementary ${ }^{2}$ Material 8 and Fig. 10) that show different textures and degrees of chemical and textural equilibrium despite likely forming at the same pressure. O1gabbronorite DC93b show somewhat larger compositional heterogeneities and lower $\mathrm{Al}^{\mathrm{IV}}$ and $\mathrm{Fe}^{3+}$ in clinopyroxene compared to troctolite DC93a (Supplementary ${ }^{2}$ Material 5), which is most likely related to a difference in bulk composition. This provides an opportunity to test the effect of such heterogeneities on av $P$ calculations with SCO1P. Calculated pressures for samples DC93a and DC93b are in good agreement $(2.67 \pm 1.35$ vs. 2.81 $\pm 1.55 \mathrm{kbar})$, supporting the robustness of average $P$.

The geobarometric results obtained for these samples give an estimate of the pressures of magma storage and crystallization in southern Dominica. Overall, the calculated pressures are in agreement with the range inferred by observational and experimental studies on magmas and cumulate rocks from the Lesser Antilles (i.e., mostly 1.0-5.0 kbar for gabbroic assemblages; cf. Pichavant and Macdonald 2007; Stamper et al. 2014b; Melekhova et al. 2015; Cooper et al. 2016). Pressure calculated for the Cpx-Amph-gabbronorite DC91 (1.94 \pm 1.09 kbar) agree very well with the pressures of orthopyroxene and plagioclase crystallization in lavas from southern Dominica ( $\sim 2$ kbar; Gurenko et al. 2006), estimated using melt inclusion data and $\mathrm{H}_{2} \mathrm{O}-\mathrm{CO}_{2}$ solubility models. Considering an average density $(\bar{\rho})$ of the crust of $2800 \mathrm{~kg} / \mathrm{m}^{3}$, the calculated $\bar{P} \pm \sigma_{\bar{P}}$ for this Cpx-Amph-gabbronorite corresponds to a depth of $7.1 \pm 4.0 \mathrm{~km}$, which agrees with the estimated hypocenters of deep volcanic earthquakes in the nearby Plat Pays volcanic complex (2-6 km; Lindsay et al. 2003), thought to result from pressurization of the magma reservoirs. Note that application of the Cpx-Opx geobarometer of Putirka (2008; his Eq. 39) to the same sample DC91, which produces an estimated value of 1.6 kbar (as stated above, $K_{\mathrm{D}}[\mathrm{Fe}-\mathrm{Mg}]^{\mathrm{Cpx}-\mathrm{Opx}}<0.95$ potentially flags incomplete equilibration), is accompanied by a model uncertainty of $\pm 2.8 \mathrm{kbar}$ (Putirka 2008). This corresponds to an uncertainty of $\pm 10.2 \mathrm{~km}$ in the estimated depth of formation.

Pressures estimated for Ol-gabbronorite DC90 and troctolite DC93a correspond to depths of $13.0 \pm 3.3$ and $9.7 \pm 4.9 \mathrm{~km}$, re- spectively. Based on the seismic reflectors identified for the crust north of Dominica (Kopp et al. 2011), such depths correspond to the middle-to-upper crust transition. Figure 11 shows how the thermobarometric results on all three xenoliths compare with the geophysical model of Kopp et al. (2011). Note that among the existing geobarometers calibrated for basaltic compositions, only the single-clinopyroxene formulations of Nimis (1995) and Putirka (2008) could be applied to these assemblages ${ }^{3}$. Application of Equation 32a of Putirka (2008) produces $P=9.4 \pm 3.1$ kbar for the sample DC90 and $P=9.9 \pm 3.1 \mathrm{kbar}$ for the sample DC93a, which corresponds to depths of $34.2 \pm 11.3$ and $36.0 \pm$ $11.3 \mathrm{~km}$, respectively, exceeding the crustal thickness in this area (27 km; Kopp et al. 2011). Overall, the successful application of average $P$ to these samples suggest that future studies on a more extensive xenolith suite from Dominica and elsewhere in the Lesser Antilles arc, combined with petrological and geophysical observations, may help to constrain the lithological structure of the crust with a precision not previously achievable.

\section{Mafic and ultramafic xenoliths from Wikieup, Arizona}

Background and sample selection. The Wikieup volcanic field is located in the Arizona Transition Zone (southwestern United States), between the Basin and Range Province (BRP), a region of thinned continental crust $(20-30 \mathrm{~km})$, and the Colorado Plateau (CP), characterized by a thicker crust $(40-50 \mathrm{~km})$ that remained tectonically stable over the Phanerozoic (e.g., Bashir et al. 2011). The Wikieup volcanics host a large number of mafic and ultramafic xenoliths thought to represent portions of the underlying deep crust and upper mantle. Some of the xenoliths analyzed by McGuire (1994) and later by McGuire and Mukasa (1997) contain the assemblage SCO1P, making them suitable for application of the av $P$ method. Quantifying the thickness and nature of the crust in the Arizona Transition Zone is important to interpret the tectonic and magmatic events that shaped the lithosphere of the southwestern U.S. Consequently, a large number of geophysical investigations have been carried out in this area (e.g., Hauser et al. 1987; Parsons et al. 1992; Bashir et al. 2011, and reference therein), providing a context for our thermobarometric results. McGuire (1994) presented such an approach using gabbroic xenoliths, but due to the lack of reliable geobarometers for such assemblages, the estimated pressures were poorly constrained.

Of the xenoliths described and analyzed by McGuire (1994) and McGuire and Mukasa (1997) we used four samples, from Tertiary alkaline olivine-basalts (Wilshire 1990) on the eastern flank of the Hualuapai Mountains, that contain the assemblage SCOIP and for which mineral compositions are available. Samples WK2-9 and WKa-49a are Ol-gabbros; samples WK124 and WK1-63 are plagioclase-peridotites. The latter show higher plagioclase and lower olivine contents with respect to typical mantle peridotites, but show compositional and textural features that distinguish them from the Ol-gabbros (McGuire and Mukasa 1997). Both Pl-peridotites and gabbros show allotriomorphic-granular textures but Pl-peridotites are also often foliated. Some textural evidence of early-stage reactions between plagioclase and olivine grains has been reported (McGuire and Mukasa 1997), but compositional heterogeneity is limited to some plagioclase grains that show slight normal zoning $(<2 \%$ 
An; McGuire and Mukasa 1997). Phase compositions are shown in Figure 2 and detailed microprobe analyses are reported in McGuire (1994) and McGuire and Mukasa (1997). Olivine shows a limited variation in composition $\left(\mathrm{Fo}_{77-79}\right)$; spinel is Al-rich $\left(\mathrm{Al} /\left[\mathrm{Al}+\mathrm{Cr}+\mathrm{Fe}^{3+}\right]=0.90-0.97\right)$ with low- $\mathrm{TiO}_{2}$ contents (0.11-0.45 wt \%); clinopyroxenes are augites with $\mathrm{Al}_{2} \mathrm{O}_{3}$ contents varying from 6.91 to $7.49 \mathrm{wt} \%$; and plagioclase varies between $\mathrm{An}_{52-53}$ (pl-peridotites) and $\mathrm{An}_{58-71}$ (ol-gabbros).

Av $P$ calculations. All av $P$ calculations passed the $\chi^{2}$ test and the calculated uncertainties are notably low (0.95-1.00 kbar; Table 3). Estimated pressures are similar within the uncertainties for all four samples, but Ol-gabbros shows some apparent lower values than Pl-peridotites (Table 3). Similar estimates are obtained using COIP, with no significant difference in the calculated uncertainties (Table 3), as previously observed at $P>5 \mathrm{kbar}$ for our experimental test (cf. Figs. 5a and 5b). Note that Ol-gabbro WK2-9 and P1-peridotite WK1-63 also contain orthopyroxene, allowing $T \sigma_{\text {fit }}$ to be compared with the results of Cpx-Opx thermometry (Putirka 2008). Observed $K_{\mathrm{D}}(\mathrm{Fe}-\mathrm{Mg})^{\mathrm{Cpx}-\mathrm{Opx}}(0.94-0.95)$ are within the range recommended for the application of such thermometer (Putirka 2008). Temperatures for the Ol-gabbro WK2-9 agree fairly well (940 vs. $887^{\circ} \mathrm{C}$ ), while temperatures for the Pl-peridotite WK1-63 disagree by about $200{ }^{\circ} \mathrm{C}$ (Table 3). However, calculations for WK1-63 using $T_{0}$ estimated from Cpx-Opx thermometry $\left(T_{0}=953{ }^{\circ} \mathrm{C}\right.$ instead of $\left.T_{0}=1150{ }^{\circ} \mathrm{C}\right)$ produce relatively small differences in the calculated pressure (7.78 \pm 0.86 vs. $6.88 \pm 0.97$ kbar).

When calculated pressures for all four samples are converted to depths (Table 3), the resulting values are consistent with those suggested by McGuire (1994) and McGuire and Mukasa (1997) based on: (1) the observation that many composite xenoliths show contact between gabbros and mantle peridotites, suggesting an origin from the crust-mantle boundary (McGuire 1994), and (2) projection of calculated temperatures onto the regional geotherm (100 mW/m²; McGuire and Mukasa 1997). Our calculations

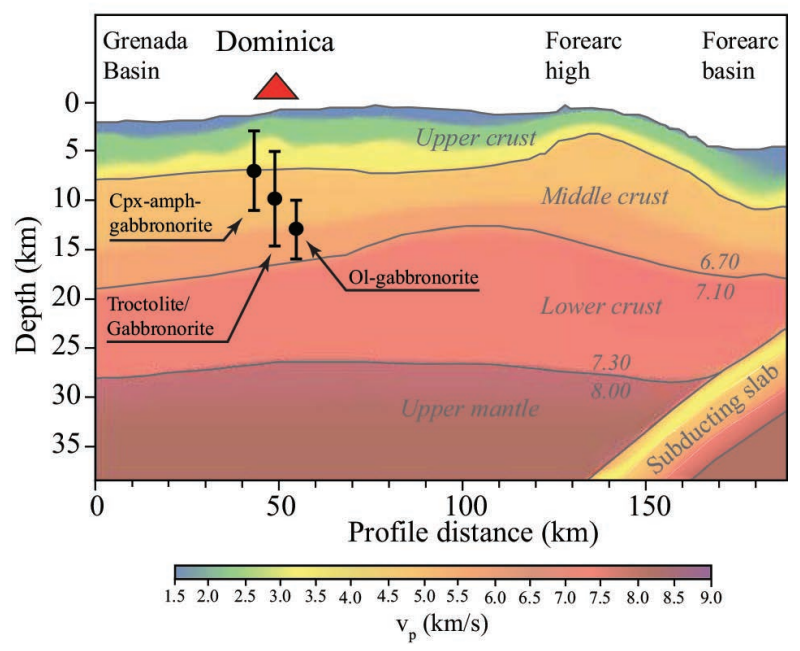

FIGURE 11. Calculated depths for the three xenoliths from Dominica, Lesser Antilles, compared with the seismic model of Kopp et al. (2011). Depths calculated as in Table 3. Numbers in the figure refer to $v_{\mathrm{p}}$ velocities $(\mathrm{km} / \mathrm{s})$. (Color online.) place more robust petrological constraints on the equilibration depths for comparison with recent geophysical investigations (Bashir et al. 2011). Figure 12 shows that the calculated depths for the Ol-gabbros and Pl-peridotites correspond closely to the lower crust levels in the integrated gravity and seismic model of Bashir et al. (2011). Note that the upper-lower crust and crustmantle boundaries sketched in Figure 12 should be viewed as transition zones and that the geophysical model has an associated uncertainty, which that is not easily quantifiable (Bashir et al. 2011). The fact that both Ol-gabbros and Pl-peridotites show comparable depths of formation is in agreement with a model of the lower continental crust characterized by a network of dikes and sills of variably mafic lithologies (McGuire 1994; Parsons et al. 1992), that can be related to the magmatic episodes that brought the xenoliths to the surface. Further application of the av $P$ method to a larger number of xenoliths, combined with detailed modal analyses and integrated geophysical-petrological models, may help to test this hypothesis.

\section{IMPLICATIONS AND FINAL RECOMMENDATIONS}

Application of average $P$ to experimental phase equilibria and well-equilibrated natural rocks has shown, for the first time, that this method can be used to reliably estimate the pressure of formation for mafic and ultramafic igneous rocks. The leastsquares minimization procedure in average $P$ makes it possible to exploit the power of internally consistent thermodynamic data sets and mutually compatible $a-x$ relations, taking into account both uncertainties and correlations in end-member properties. It represents an optimal method to deal with the inevitable inaccuracy of thermodynamic models and uncertainties on mineral compositions. We demonstrated that calculations on SCOIP equilibria, using the models refined in this work, yield: (1) good

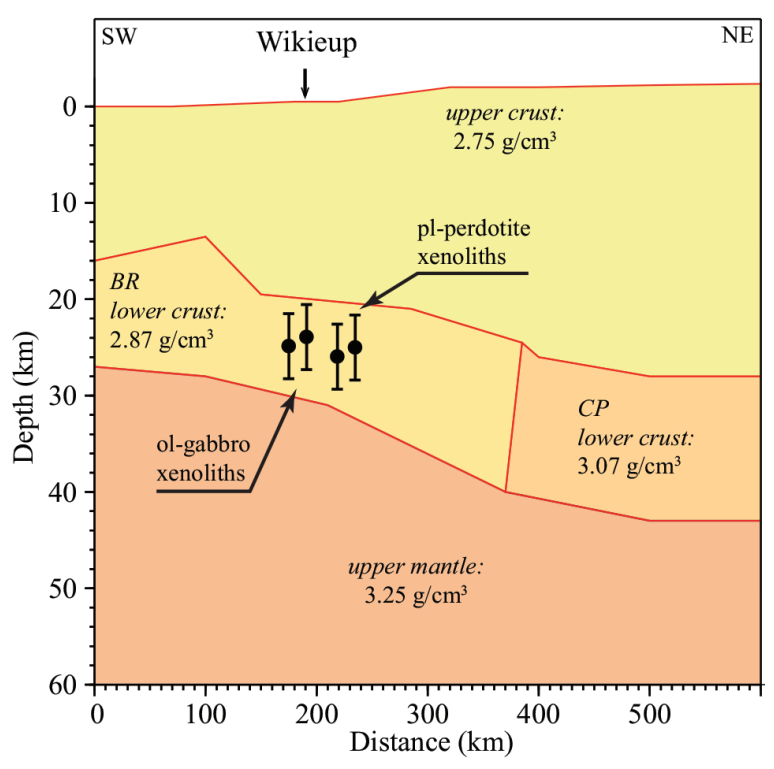

FigURE 12. Calculated depths (as Table 3) for the Ol-gabbro and Pl-peridotite xenoliths from Wikieup, shown in comparison to the density profile across the Arizona Transition Zone (Bashir et al. 2011). BR = Basin and Range; $\mathrm{CP}=$ Colorado Plateau. (Color online.) 
reproducibility of experimental pressures by av $P$ ( $P$ is predicted, within the calculated $\sigma_{\bar{P}}$, for $67 \%$ of the experimental database); (2) internal consistency of av $P$ results (i.e., $\chi^{2}$ test passed) for the majority of phase-equilibrium experiments and for the selected well-equilibrated natural assemblages; and (3) low- $P$ uncertainties $\left(\sigma_{\bar{P}}\right)$, as low as $0.9 \mathrm{kbar}$, for the same assemblages. Pressure estimates with such low uncertainties can help to characterize the key petrological processes and trace the vertical distribution of mafic and ultramafic lithologies in the upper $30-40 \mathrm{~km}$ of the lithosphere. Integration with geophysical data for the same areas affords potentially powerful insights into crustal structure.

Modifications of the existing $a-x$ models for clinopyroxene (Green et al. 2016) and spinel (Jennings and Holland 2015) were necessary to avoid some observed pressure deviations resulting from initial calculations with SCOIP. At present, we believe that the thermodynamic models used in this work are applicable to any gabbroic rock, pyroxenite or peridotite that contains olivine + clinopyroxene + plagioclase in its equilibrium assemblage, regardless of geodynamic setting. This is supported by: (1) the robustness of a multiple-reaction approach based on an internally consistent thermodynamic data set (Holland and Powell 2011), and (2) the successful tests on a database of phase-equilibrium experiments that cover a wide range of basaltic and peridotitic compositions (e.g., Figs. 5 and 6), both hydrated and nominallyanhydrous. We believe the method can be applied also to volcanic rocks, for which, however, the selection of equilibrium phase compositions might not be straightforward. Future test cases, in which a detailed textural and chemical characterization of the phenocryst assemblages will be coupled with the application of average $P$ and its fit diagnostics, will help to test this hypothesis.

For equilibrated assemblages including spinel, calculations with SCO1P equilibria are always preferred, since COIP slightly overestimate pressures (by 1-2 kbar) at upper-middle crust conditions $(P<5$ kbar $)$. Calculations with SCOlP should be possible for a large number of mafic/ultramafic rocks, as spinel is a ubiquitous phase in many natural gabbroic and basaltic rocks, and sometimes coexists with plagioclase in shallow mantle peridotites/pyroxenites. Calculations with COIP, on the other hand, are more likely to be needed for plagioclase-only peridotites/pyroxenites. Importantly, the latter typically form at lower crust and uppermost mantle conditions ( $P>5$ kbar; e.g., Kelemen et al. 2007; Borghini et al. 2011), corresponding to those pressures at which COlP calculations show low uncertainties and are consistent with SCOIP based on tests on experimental (Fig. 5) and natural samples (Table 3).

The reliability of av $P$ calculations on natural samples relies on the attainment of equilibrium in the assemblage. If the assemblage shows slight intra- or inter-grain chemical heterogeneities, care should be taken to select mineral compositions that are likely to be at equilibrium, as shown by the application to the cumulate xenoliths from Dominica (Fig. 10). Second, when using our sets of independent reactions (Fig. 4), temperature estimates for the sample need to be well constrained if the assemblage equilibrated at $P<5 \mathrm{kbar}$. To estimate the true $T$ of equilibration, it may be possible to use existing thermometers, such as the Cpx-Opx thermometer of Putirka (2008) or the Ca-in-olivine thermometer of Shejwalkar and Coogan (2013). Otherwise we suggest running av $P$ calculations at different temperature $T_{0}$, and select that which produces the lowest residuals $\left(\sigma_{\text {fit }}\right)$ in the average $P$ minimization routine (Fig. 7).

Further work is planned to extend the average $P$ approach to a wider range of phase assemblages. This will entail testing and potential modification of thermodynamic models for orthopyroxene, amphibole, and ilmenite, which are also common constituents of mafic and ultramafic igneous rocks in various settings. Using such a set of models, it will be possible to obtain mutually consistent pressure estimates for a wide range of igneous rocks.

\section{ACKNOWLEDGMENTS}

We thank Roger Powell for helpful discussions, especially his insight into and debugging of the average $P$ algorithm. Susanne Skora provided many useful suggestions in the original formulation of this project and, together with Richard Arculus and Richard Brooker, assisted in collection of the Dominica xenoliths. John Schumacher and Lena Melekhova are thanked for the useful discussions. Francesco Narduzzi is thanked for the valuable comments on preliminary versions of the manuscript. Silvio Mollo and Alexey Ariskin are thanked for their helpful and constructive reviews, and Renat Almeev for his editorial handling. This project was funded by NERC grant NE/K014978/1.

\section{REFERENCES CITED}

Almeev, R.R., Holtz, F., Koepke, K., Parat, F., and Botcharnikov, R.R. (2007) The effect of $\mathrm{H}_{2} \mathrm{O}$ on olivine crystallization in MORB: Experimental calibration at $200 \mathrm{MPa}$. American Mineralogist, 92, 670-674.

Andujar, J., Scaillet, B., Pichavant, M., and Druitt, T.H. (2015) Differentiation conditions of a basaltic magma from Santorini, and its bearing on the production of andesite in arc settings. Journal of Petrology, 56, 765-794.

Arculus, R., and Wills, K. (1980) The petrology of igneous blocks and inclusions from the Lesser Antilles island arc. Journal of Petrology, 21, 143-168.

Baker, M.B., and Stolper, E.M. (1994) Determining the composition of high-pressure mantle melts using diamond aggregates. Geochimica et Cosmochimica Acta, $58,2811-2827$.

Barclay, J., and Carmichael, I.S.E. (2004) A hornblende basalt from Wester Mexico: Water-saturated phase relations constrain a pressure-temperature window of eruptibility. Journal of Petrology, 45, 485-506.

Bartels, K.S., Kinzler, R.J., and Grove, T.L. (1991) High pressure phase relations of primitive high-alumina basalts from Medicine Lake volcano, northern California. Contributions to Mineralogy and Petrology, 108, 253-270.

Bashir, L., Gao, S.S., Liu, K.H., and Mickus, K. (2011) Crustal structure and evolution beneath the Colorado Plateau and the southern Basin and Range Province: Results from receiver function and gravity studies. Geochemistry, Geophysics, Geosystems, 12, doi: 10.1029/2011GC003563.

Berman, R.G. (1988) Internally-consistent thermodynamic data for minerals in the system $\mathrm{Na}_{2} \mathrm{O}-\mathrm{K}_{2} \mathrm{O}-\mathrm{CaO}-\mathrm{MgO}-\mathrm{FeO}-\mathrm{Fe}_{2} \mathrm{O}_{3}-\mathrm{Al}_{2} \mathrm{O}_{3}-\mathrm{SiO}_{2}-\mathrm{TiO}_{2}-\mathrm{H}_{2} \mathrm{O}-\mathrm{CO}_{2}$. Journal of Petrology, 29, 445-522.

(1991) Thermobarometry using multi-equilibrium calculations: A new technique with petrological applications. Canadian Mineralogist, 29, 833-855.

Blatter, D.L., Sisson, T.W., and Hankins, W.B. (2013) Crystallization of oxidized, moderately hydrous arc basalt at mid- to lower-crustal pressures: Implications for andesite genesis. Contributions to Mineralogy and Petrology, 166, 861-886.

Borghini, G., Fumagalli, P., and Rampone, E. (2010) The stability of plagioclase in the upper mantle: subsolidus experiments on fertile and depleted lherzolite. Journal of Petrology, 51, 229-254.

(2011) The geobarometric significance of plagioclase in mantle peridotites: a link between nature and experiments. Lithos, 126, 42-53.

Boyd, F.R., England, J.L., and Davis, B.T.C. (1964) Effect of pressure on the melting and polymorphism on enstatite, $\mathrm{MgSiO}_{3}$. Journal of Geophysical Research, $69,2101-2109$.

Boynton, C.H., Westbrook, G.K., Bott, M.H.P., and Long, R.E. (1979) A seismic refraction investigation of crustal structure beneath the Lesser Antilles island arc. Geophysical Journal International, 58, 371-393.

Bryndzia, L.T., and Wood, B.J. (1990) Oxygen thermobarometry of abyssal spinel peridotites: the redox state and $\mathrm{C}-\mathrm{O}-\mathrm{H}$ volatile composition of the Earth's suboceanic upper mantle. American Journal of Science, 290, 1093-1116.

Chalot-Prat, F., Falloon, T.J., Green, D.H., and Hibberson, W.O. (2010) An experimental study of liquid compositions in equilibrium with plagioclase + spinel lherzolite at low pressures (0.75 GPa). Journal of Petrology, 51, 2349-2376. (2013) Melting of plagioclase + spinel lherzolite at low pressures $(0.5 \mathrm{GPa})$ : An experimental approach to the evolution of basaltic melt during mantle refertilisation at shallow depths. Lithos, 172-173, 61-80.

Christeson, G.L., Mann, P., Escalona, A., and Aitken, T.J. (2008) Crustal structure of the Caribbean-northeastern South America arc-continent collision zone. Journal of Geophysical Research, 113, B08104, doi:10.1029/2007JB005373.

Cooper, G.F., Davidson, J.P., and Blundy, J.D. (2016) Plutonic xenoliths from Mar- 
tinique, Lesser Antilles: Evidence for open system processes and reactive melt flow in island arc crust. Contributions to Mineralogy and Petrology, 171, 87.

Di Carlo, I., Pichavant, M., Rotolo, S., and Scaillet, B. (2006) Experimental crystallization of a high-K arc basalt: The Golden Pumice, Stromboli Volcano (Italy). Journal of Petrology, 47, 1317-1343.

Diener, J.F.A., Powell, R., White, R.W., and Holland, T.J.B. (2007) A new thermodynamic model for clino- and orthoamphiboles in the system $\mathrm{Na}_{2} \mathrm{O}-\mathrm{CaO}-\mathrm{FeO}-$ $\mathrm{MgO}-\mathrm{Al}_{2} \mathrm{O}_{3}-\mathrm{SiO}_{2}-\mathrm{H}_{2} \mathrm{O}-\mathrm{O}$. Journal of Metamorphic Geology, 25, 631-656.

Draper, D.S., and Johnston, A.D. (1992) Anhydrous PT phase relations of an Aleutian high-MgO basalt: An investigation of the role of olivine-liquid reaction in the generation of arc high-alumina basalts. Contributions to Mineralogy and Petrology, 112, 501-519.

Droop, G.T.R. (1987) A general equation for estimation of $\mathrm{Fe}^{3+}$ concentrations in ferromagnesian silicates and oxides from microprobe analysis, using stoichiometry criteria. Mineralogical Magazine, 51, 431-435.

Erdmann, S., Martel, C., Pichavant, M., and Kushnir, A. (2014) Amphibole as an archivist of magmatic crystallization conditions: Problems, potential, and implications for inferring magma storage prior to the paroxysmal 2010 eruption of Mount Merapi, Indonesia. Contributions to Mineralogy and Petrology, 167, 1016.

Falloon, T.J., Danyushevsky, L.V., Ariskin, A., Green, D.H., and Fors, C.E. (2007) The application of olivine geothermometry to infer crystallization temperatures of parental liquids: Implications for the temperature of MORB magmas. Chemical Geology, 241, 207-233.

Feig, S.T., Koepke, J., and Snow, J.E. (2006) Effect of water on tholeiitic basalt phase equilibria: an experimental study under oxidizing conditions. Contributions to Mineralogy and Petrology, 152, 611-638.

(2010) Effect of oxygen fugacity and water on phase equilibria of a hydrous tholeiitic basalt. Contributions to Mineralogy and Petrology, 160, 551-568.

Fumagalli, P., Borghini, G., Rampone, E., and Poli, S. (2017) Experimental calibration of Forsterite-Anorthite-Ca-Tschermak-Enstatite (FACE) geobarometer for mantle peridotites. Contributions to Mineralogy and Petrology, 172, 38.

Gasparik, T. (1990) A thermodynamic model for the enstatite-diopside join. American Mineralogist, 75, 1080-1091.

Ghiorso, M.S., and Evans, B.W. (2008) Thermodynamics of rhombohedral oxide solid solutions and a revision of the Fe-Ti two-oxide geothermometer and oxygenbarometer. American Journal of Science, 308, 957-1039.

Ghiorso, M.S., and Sack, R.O. (1995) Chemical mass transfer in magmatic processes, IV, A revised and internally consistent thermodynamic model for the interpolation and extrapolation of liquid-solid equilibria in magmatic systems at elevated temperatures and pressures. Contributions to Mineralogy and Petrology, 119, 197-212.

Giaramita, M., and Day, H. (1990) Error propagation in calculations of structural formulas. American Mineralogist, 75, 170-182.

Gordon, T.M. (1992) Generalized thermobarometry: Solution of the inverse chemical equilibrium problem using data for individual species. Geochimica et Cosmochimica Acta, 56, 1793-1800.

Green, E.C.R., Holland, T.J.B., and Powell, R. (2007) An order- disorder model for omphacitic pyroxenes in the system jadeite-diopside-hedenbergite-acmite, with applications to eclogitic rocks. American Mineralogist, 92, 1181-1189.

Green, E.C.R., Holland, T.J.B., Powell, R., and White, R.W. (2012) Garnet and spinel lherzolite assemblages in $\mathrm{MgO}-\mathrm{Al}_{2} \mathrm{O}_{3}-\mathrm{SiO}_{2}$ and $\mathrm{CaO}-\mathrm{MgO}-\mathrm{Al}_{2} \mathrm{O}_{3}-\mathrm{SiO}_{2}$ : thermodynamic models and an experimental conflict. Journal of Metamorphic Geology, 30, 561-577.

Green, E.C.R., White, R.W., Diener, J.F.A., Powell, R., Holland, T.J.B., and Palin, R.M. (2016) Activity-composition relations for the calculation of partial melting equilibria in metabasic rocks. Journal of Metamorphic Geology, 34, 845-869.

Grove, T.L., and Bryan, W.B. (1983) Fractionation of pyroxene-pyric MORB at low pressure: An experimental study. Contributions to Mineralogy and Petrology, 84, 293-309.

Grove, T.L., and Juster, T.C. (1989) Experimental investigations of low-Ca pyroxene stability and olivine-pyroxene-liquid equilibria at 1-atm in natural basaltic and andesitic liquids. Contributions to Mineralogy and Petrology, 103, 287-305.

Grove, T.L., Donnelly-Nolan, J.M., and Housh, T. (1997) Magmatic processes that generated the rhyolite of Glass Mountain, Medicine Lake volcano, N. California. Contributions to Mineralogy and Petrology, 127, 205-223.

Grove, T.L., Elkins-Tanton, L.T., Parman, S.W., Chatterjee, N., Muntener, O., and Gaetani, G.A. (2003) Fractional crystallization and mantle-melting controls on calc-alkaline differentiation trends. Contributions to Mineralogy and Petrology, $145,515-533$.

Gualda, G.A.R., Ghiorso, M.S., Lemons, R.V., and Carley, T.L. (2012) RhyoliteMELTS: a modified calibration of MELTS optimized for silica-rich, fluid-bearing magmatic systems. Journal of Petrology, 53, 875-890.

Gurenko, A.A., Trumbull, R.B., Thomas, R., and Lindsay, J.L. (2006) A melt inclusion record of volatiles, trace elements and $\mathrm{Li}-\mathrm{B}$ isotope variations in a single magma system from the Plat Pays Volcanic Complex, Dominica, Lesser Antilles. Journal of Petrology, 46, 2495-2526.

Hackler, R.T., and Wood, B.J. (1989) Experimental determination of Fe and $\mathrm{Mg}$ exchange between garnet and olivine and estimation of $\mathrm{Fe}-\mathrm{Mg}$ mixing properties in garnet. American Mineralogist, 74, 994-999.
Hamada, M., and Fuji, T. (2008) Experimental constraints on the effects of pressure and $\mathrm{H}_{2} \mathrm{O}$ on the fractional crystallization of high-Mg island arc basalt. Contributions to Mineralogy and Petrology, 155, 767-790.

Hauser, C., Gephart, J., Latham, T., Oliver, J., Kaufman, S., Brown, L., and Lucchitta, I. (1987) COCORP Arizona transect: Strong crustal reflections and offset Moho beneath the transition zone. Geology, 15, 1103-1106.

Holland, T., and Blundy, J. (1994) Non-ideal interactions in calcic amphiboles and their bearing on amphibole-plagioclase thermometry. Contributions to Mineralogy and Petrology, 116, 433-447.

Holland, T.J.B., and Powell, R. (1985) An internally consistent thermodynamic dataset with uncertainties and correlations. II. Data and results. Journal of Metamorphic Geology, 3, 343-370.

(1990) An internally consistent thermodynamic dataset with uncertainties and correlations: The system $\mathrm{Na}_{2} \mathrm{O}-\mathrm{K}_{2} \mathrm{O}-\mathrm{CaO}-\mathrm{MgO}-\mathrm{MnO}-\mathrm{FeO}-\mathrm{Fe}_{2} \mathrm{O}_{3}-\mathrm{Al}_{2} \mathrm{O}_{3}$ $\mathrm{SiO}_{2}-\mathrm{TiO}_{2}-\mathrm{C}-\mathrm{H}_{2}-\mathrm{O}_{2}$. Journal of Metamorphic Geology, 8, 89-124. (1998) An internally-consistent thermodynamic dataset for phases of petrological interest. Journal of Metamorphic Geology, 16, 309-344.

(2003) Activity-composition relations for phases in petrological calculations: An asymmetric multicomponent formulation. Contributions to Mineralogy and Petrology, 145, 492-501.

(2011) An improved and extended internally-consistent thermodynamic dataset for phases of petrological interest, involving a new equation of state for solids. Journal of Metamorphic Geology, 29, 333-383.

Howe, T.M., Lindsay, J.M., and Shane, P. (2015) Evolution of young andesitic-dacitic magmatic systems beneath Dominica, Lesser Antilles. Journal of Volcanology and Geothermal Research, 297, 69-88.

Husen, A., Almeev, R.R., and Holtz, F. (2016) The effect of $\mathrm{H}_{2} \mathrm{O}$ on pressure and multiple saturation and liquid line of descent in basalt from the Shatsky Rise. Journal of Petrology, 57, 309-344.

Jennings, E.S., and Holland, T.J.B. (2015) A simple thermodynamic model for melting of peridotite in the system NCFMASOCr. Journal of Petrology, 56, 869-892.

Juster, T.C., and Grove, T.L. (1989) Experimental constraints on the generation of FeTi basalts, andesites, and riodacites at the Galapagos Spreading Center, $85^{\circ} \mathrm{W}$ and $95^{\circ} \mathrm{W}$. Journal of Geophysical Research, 94, 9251-9274.

Kawamoto, T. (1996) Experimental constraints on differentiation and $\mathrm{H}_{2} \mathrm{O}$ abundance of calc-alkaline magmas. Earth and Planetary Science Letters, 144, 577-589.

Kelemen, P.B., Kikawa, E., Miller, D.J., and Shipboard Scientific Party (2007) Leg 209 summary: Processes in a 20-km-thick conductive boundary layer beneath the Mid-Atlantic Ridge, $14^{\circ}-16^{\circ}$ N. In P.B. Kelemen, E. Kikawa, and D.J. Miller, Eds., Proceedings of the ODP, Science Results 209, 1-33. College Station, Texas, U.S.A.

Kennedy, A.K., Grove, T.L., and Johnson, R.W. (1990) Experimental and major element constraints on the evolution of lavas from Lihir Island, Papua New Guinea. Contributions to Mineralogy and Petrology, 104, 722-734.

Kinzler, R.J., and Grove, T.L. (1992) Primary magmas of Mid-Ocean Ridge Basalts 1. Experiments and methods. Journal of Geophysical Research, 97, 6885-6906.

Kopp, H., Weinzierl, W., Becel, A., Charvis, P., Evain, M., Flueh, E.R., Gailler, A., Galve, A., Hirn, A., Kandilarov, A., Klaeschen, D., Laigle, M., Papenberg, C., Planert, L., and Roux, E. (2011) Deep structure of the central Lesser Antilles Island Arc: relevance for the formation of continental crust. Earth and Planetary Science Letters, 304, 121-134.

Lindsay, J., Stasiuk, M., and Shepherd, J. (2003) Geological history and potential hazards of the late-Pleistocene to Recent Plat Pays volcanic complex, Dominica, Lesser Antilles. Bulletin of Volcanology, 65, 201-220.

Lindsay, J., Trumbull, R.B., and Siebel, W. (2005) Geochemistry and petrogenesis of late Pleistocene to Recent volcanism in Southern Dominica, Lesser Antilles. Journal of Volcanology and Geothermal Research, 148, 253-294.

Lindsley, D. (1981) The formation of pigeonite on the join hedenbergite-ferrosilite at $11.5 \mathrm{kbar}$ and $15 \mathrm{kbar}$ : experiments and a solution model. American Mineralogist, 66, 1175-1182.

- (1983) Pyroxene thermometry. American Mineralogist, 68, 477-493.

Loucks, R.R. (1996) A precise olivine-augite Mg-Fe exchange geothermometer Contributions to Mineralogy and Petrology, 125, 140-150.

Macdonald, R., Hawkesworth, C.J., and Heath, E. (2000) The Lesser Antilles volcanic chain: a study in arc magmatism. Earth Science Review, 49, 1-76.

Mahood, G.A., and Baker, D.R. (1986) Experimental constraints on depths of fractionation of midly alkali basalts and associated felsic rocks: Pantelleria, Strait of Sicily. Contributions to Mineralogy and Petrology, 93, 251-264.

Mandler, B.E., Donnelly-Nolan, J.M., and Grove, T.L. (2014) Straddling the tholeiitic/ calcalkaline transition: The effects of modest amounts of water on magmatic differentiation at Newberry Volcano, Oregon. Contributions to Mineralogy and Petrology, 168, 1066.

McGuire, A.V. (1994) Southern Basin and Range province crust-mantle boundary: evidence from gabbroic xenoliths, Wikieup, Arizona. Journal of Geophysical Research, 99, 24263-24273.

McGuire, A.V., and Mukasa, S.B. (1997) Magmatic modification of the uppermost mantle beneath the Basin and Range to Colorado Plateau Transition Zone: Evidence from xenoliths, Wikieup, Arizona. Contributions to Mineralogy and Petrology, 128, 52-65. 
Melekhova, E., Blundy, J., Robertson, R., and Humphreys, M.C.S. (2015) Experimental evidence for polybaric differentiation of primitive arc basalt beneath $\mathrm{St}$. Vincent, Lesser Antilles. Journal of Petrology, 56, 161-192.

Mikhail, E.M. (1976) Observations and Least Squares. Dun Donnelly, New York.

Molina, J.F., Moreno, J.A., Castro, A., Rodruiguez, C., and Fershtater, G.B. (2015) Calcic amphibole thermobarometry in metamorphic and igneous rocks: new calibrations based on plagioclase/amphibole Al-Si partitioning and amphiboleliquid $\mathrm{Mg}$ partitioning. Lithos, 232, 286-305.

Mollo, S., Del Gaudio, P., Ventura, G., Iezzi, G., and Scarlato, P. (2010) Dependence of clinopyroxene composition on cooling rate in basaltic magmas: Implications for thermobarometry. Lithos, 118, 302-312.

Moore, G., and Carmichael, I.S.E. (1998) The hydrous phase equilibria (to 3 kbar) of an andesite and basaltic andesite from western Mexico: Constraints on water content and conditions of phenocryst growth. Contributions to Mineralogy and Petrology, 130, 304-319.

Morimoto, N., Fabries, J., Ferguson, A.K., Ginzburg, I.V., Ross, M., Seifert, F.A., Zussman, J., Aoki, K., and Gottardi, G. (1988) Nomenclature of pyroxenes. American Mineralogist, 73, 1123-1133.

Neave, D.A., and Putirka, K.D. (2017) A new clinopyroxene-liquid barometer, and implications for magma storage pressures under Icelandic rift zones. American Mineralogist, 102, 777-794.

Nekvasil, H., Dondolini, A., Horn, J., Filiberto, J., Long, H., and Lindsley, D.H. (2004) The origin and evolution of silica-saturated alkalic suites: An experimental study. Journal of Petrology, 45, 693-721.

Nimis, P. (1995) A clinopyroxene geobarometer for basaltic systems based on crystalsstructure modeling. Contributions to Mineralogy and Petrology, 121, 115-125.

O'Neill, H.St.C., and Pownceby, M.I. (1993) Thermodynamic data from redox reactions at high temperatures. I. An experimental and theoretical assessment of the electrochemical method using stabilized zirconia electrolytes, with revised values for the $\mathrm{Fe}-" \mathrm{FeO}$ ", $\mathrm{Co}-\mathrm{CoO}, \mathrm{Ni}-\mathrm{NiO}$ and $\mathrm{Cu}-\mathrm{Cu}_{2} \mathrm{O}$ oxygen buffers, and new data for the W- $\mathrm{WO}_{2}$ buffer. Contributions to Mineralogy and Petrology, 114, 296-314.

Parat, F., Streck, M.J., Holtz, F., and Almeev, R. (2014) Experimental study into the petrogenesis of crystal-rich basaltic to andesitic magmas at Arenal volcano. Contributions to Mineralogy and Petrology, 168, 1040.

Parsons, T., Howiem, J.M., and Thompson, G.A. (1992) Seismic constraints on the nature of lower crustal reflectors beneath the extending southern Transition Zone of the Colorado Plateau, Arizona. Journal of Geophysical Research, 97, 12391-12407.

Pichavant, M., and Macdonald, R. (2007) Crystallization of primitive basaltic magmas at crustal pressures and genesis of the calc-alkaline igneous suite: experimental evidence from St Vincent, Lesser Antilles arc. Contributions to Mineralogy and Petrology, 154, 535-558.

Pichavant, M., Martel, C., Bourdier, J-L., and Scaillet, B. (2002) Physical conditions, structure and dynamics of a zoned magma chamber: Mount Pele (Martinique, Lesser Antilles arc). Journal of Geophysical Research, 107, doi:10.1029/2001JB000315.

Powell, R. (1985) Geothermometry and geobarometry: A discussion. Journal of the Geological Society, London, 142, 29-38.

Powell, R., and Holland, T.J.B. (1988) An internally consistent thermodynamic dataset with uncertainties and correlations: 3: application methods, worked examples and a computer program. Journal of Metamorphic Geology, 6, 173-204. (1993) On the formulation of simple mixing models for complex phases. American Mineralogist, 78, 1174-1180.

(1994) Optimal geothermometry and geobarometry. American Mineralogist, $79,120-133$.

- (2008) On thermobarometry. Journal of Metamorphic Geology, 26, 155-179.

Putirka, K.D. (2008) Thermometers and barometers for volcanic systems. Reviews in Mineralogy and Geochemistry, 69, 61-120.

(2016a) Rates and styles of planetary cooling on Earth, Moon, Mars, and Vesta, using new models for oxygen fugacity, ferric-ferrous ratios, olivine-liquid $\mathrm{Fe}-\mathrm{Mg}$ exchange, and mantle potential temperature. American Mineralogist, $101,819-840$.

(2016b) Amphibole thermometers and barometers for igneous systems and some implications for eruption mechanisms of felsic magmas at arc volcanoes.
American Mineralogist, 101, 841-858.

Ridolfi, F., and Renzulli, A. (2012) Calcic amphiboles in calc-alkaline and alkaline magmas: Thermobarometric and chemometric empirical equations valid up to $1130^{\circ} \mathrm{C}$ and $2.2 \mathrm{GPa}$. Contributions to Mineralogy and Petrology, 163, 877-895.

Sack, R.O., Walker, D., and Carmichael, I.S.E. (1987) Experimental petrology of alkalic lavas: constraints on cotectics of multiple saturation in natural basic liquids. Contributions to Mineralogy and Petrology, 96, 1-23.

Scoates, J.S., Lo Cascio, M., Weis, D., and Lindsley, D.H. (2006) Experimental constraints on the origin and evolution of mildly alkalic basalts from the Kerguelen Archipelago, Southeast Indian Ocean. Contributions to Mineralogy and Petrology, 151, 582-599.

Shejwalkar, A., and Coogan, L.A. (2013) Experimental calibration of the roles of temperature and composition in the Ca-in-olivine geothermometer at $0.1 \mathrm{MPa}$. Lithos, 177, 54-60.

Sisson, T.W., and Grove, T.L. (1993) Experimental investigations of the role of $\mathrm{H}_{2} \mathrm{O}$ in calc-alkaline differentiation and subduction zone magmatism. Contributions to Mineralogy and Petrology, 113, 143-166.

Stamper, C.C., Melekhova, E., Blundy, J.D., Arculus, R.J., Humphreys, M.C.S., and Brooker, R.A. (2014a) Oxidised phase relations of a primitive basalt from Grenada, Lesser Antilles. Contributions to Mineralogy and Petrology, 167, 1-20.

Stamper, C.C., Blundy, J.D., Arculus, R.J., and Melekhova, E. (2014b) Petrology of plutonic xenoliths and volcanic rocks from Grenada, Lesser Antilles. Journal of Petrology, 55, 1353-1387.

Streckeisen, A. (1976) To each plutonic rock its proper name. Earth Science Reviews, $12,1-33$.

Takagi, D., Sato, H., and Nakagawa, M. (2005) Experimental study of a low-alkali tholeiite at 1-5 kbar: Optimal condition for the crystallization of high-An plagioclase in hydrous arc tholeiite. Contributions to Mineralogy and Petrology, $149,527-540$.

Tollan, P., Bindeman, I., and Blundy, J. (2012) Cumulate xenoliths from St. Vincent, Lesser Antilles Island Arc: A window into upper crustal differentiation of mantlederived basalts. Contributions to Mineralogy and Petrology, 163, 189-208.

Toplis, M., and Carroll, M.R. (1995) An experimental study of the influence of oxygen fugacity on Fe-Ti oxide stability, phase relations, and mineral-melt equilibria in ferro-basaltic systems. Journal of Petrology, 36, 1137-1170.

Turnock, A.C., and Lindsley, D.H. (1981) Experimental determination of pyroxene solvi for $\leq 1 \mathrm{kbar}$ at 900 and $1000^{\circ} \mathrm{C}$. Canadian Mineralogist, 19, 255-267.

Wagner, T.P., Donnelly-Nolan, J.M., and Grove, T.L. (1995) Evidence of hydrous differentiation and crystal accumulation in the low-MgO, high- $\mathrm{Al}_{2} \mathrm{O}_{3}$ Lake Basalt from Medicine Lake volcano, California. Contributions to Mineralogy and Petrology, 121, 201-216.

Wells, P.R.A. (1977) Pyroxene thermometry in simple and complex systems. Contributions to Mineralogy and Petrology, 62, 129-139.

White, R.W., Powell, R., Holland, T.J.B., Johnson, T.E., and Green, E.C.R. (2014) New mineral activity-composition relations for thermodynamic calculations in metapelitic systems. Journal of Metamorphic Geology, 32, 261-286.

Wilshire, H.G. (1990) Lithology and evolution of the crust-mantle boundary region in the southwestern Basin and Range province. Journal of Geophysical Research, $95,649-665$.

MANUSCRIPT RECEIVED APRIL 5, 2017

MANUSCRIPT ACCEPTED AUGUST 11, 2017

MANUSCRIPT HANDLED BY RENAT ALMEEY

\section{Endnotes}

${ }^{1}$ We use the term "thermodynamic model" to refer to both the thermodynamic properties of the end-members and the constituent $a-x$ relations.

${ }^{2}$ Deposit item AM-17-126154, Supplemental Material. Deposit items are free to all readers and found on the MSA web site, via the specific issue's Table of Contents (go to http://www.minsocam.org/MSA/AmMin/TOC/2017/Dec2017 data/ Dec2017 data.html).

${ }^{3}$ Note that there are no tests for equilibrium (e.g., Putirka 2008) for clinopyroxeneonly models. 